\title{
The Categorization and Structural Prediction of Transition Metal Carbonyl Clusters Using 14n Series Numerical Matrix
}

\author{
Enos Masheija Rwantale Kiremire \\ Correspondence: Enos Masheija Rwantale Kiremire, Department of Chemistry and Biochemistry,University of Namibia, \\ Private Bag 13301, Windhoek. E-mail: kiremire15@yahoo.com
}

Received: September 22, 2015 Accepted: October 8, 2015 Online Published: January 21, 2016

doi:10.5539/ijc.v8n1p109

URL: http://dx.doi.org/10.5539/ijc.v8n1p109

\begin{abstract}
A matrix table of valence electron content of carbonyl clusters has been created using the $14 n$-based series. The numbers so generated form an array of series which conform precisely with valence electron contents of carbonyl clusters. The renowned 18 electron rule is a special case of $14 n+4$ series. Similarly, the 16 electron rule is another special case of the $14 n+2$ series. Categorization of the carbonyl clusters using the matrix table of series has been demonstrated. The table is so organized that clusters numerically represented can easily be compared and analyzed. The numbers that are diagonally arranged from right to left represent capping series. The row from right to left represents a decrease in valence electron content with increase in cluster linkages. The variation of cluster shapes of constant number of skeletal elements especially four or more may be monitored or compared with the variation with the valence electron content.

Keywords: valence electron content, carbonyl clusters, isolobal series, 18 and 16 electron rule, valence electron matrix table, shapes of carbonyl clusters, capping and decapping series, diagonal relationship, fragments

\section{Introduction}

The borane and transition metal carbonyl clusters have been of great interest to chemists for considerable long time due to the special geometries, unusual bonding framework and promising wide range of industrial applications (Stock, 1933; Kobayashi, 2007). The Wade-Mingos rules have been extremely helpful in deducing the cluster geometries (Mingos, 1984;Wade, 1976; Jemmis, 1984, 2001,2002,2003,2005,2006,2008;King, 2002; Welch, 2013). Furthermore, it has been found that carbonyl clusters and some main group clusters can be categorized using $4 \mathrm{n}$ and $14 \mathrm{n}$ series (Kiremire, 2014, 2015). Since the $14 n$ series $(14 n \pm q)$ run parallel to $4 n$ series $(4 n \pm q)$, the $4 n$ series can be used instead of the $14 n$ series. This is because it is easier to use $4 \mathrm{n}$ rather than $14 \mathrm{n}$ series. We have also demonstrated that the $14 \mathrm{n}$ and $4 \mathrm{n}$ series can be used to categorize and predict shapes of clusters of carbonyls, boranes and heteroboranes (Kiremire, 2014,2015). In this paper, a numerical sequences based on 14n series that give precise valence contents of clusters and their arrangements into series is presented. In this way, using the valence content of a cluster formula, the cluster can readily be categorized and its possible geometry predicted.
\end{abstract}

\section{Results and Discussion}

\subsection{Creation of a Valence Electron Content Table for Carbonyl Clusters}

A matrix of numbers has been created using the $14 \mathrm{n}$-based series. The series have been chosen from the range $\mathrm{S}=$ $14 \mathrm{n}-12$ to $14 \mathrm{n}+12$ and for $\mathrm{n}=1$ to 30 . Consider the first row of the matrix, when $\mathrm{S}=14 \mathrm{n}-12$, and $\mathrm{n}=1, \mathrm{~S}=14(1)-12=$ 2. For $\mathrm{S}=14 \mathrm{n}-10$, when $\mathrm{n}=1, \mathrm{~S}=14(1)-10=4$, and $\mathrm{S}=14 \mathrm{n}-8=14(1)-8=6$. The rest of $\mathrm{S}$ values are, 8,10 , $12,14,16,18,20,22,24$ and 26 . The $\mathrm{S}$ values are similarly obtained for the second row when $\mathrm{n}=2$ and for other rows. These results are shown in Table 1.

\subsection{The Extraction of Carbonyl Clusters from the Table}

We can use Table 1 to extract carbonyl clusters as needed. Furthermore, it is quite interesting to discover that the table gives precise valence content of the cluster skeletal fragments including the stable mono-skeletal carbonyl complexes that obey the famous 18-electron rule. For instance, when $n=1$, and $S=14 n+0=14$. This means the valence content is 14 for a single skeletal element. Suitable transition metal fragments are $\left[\mathrm{Os}(\mathrm{CO})_{3}\right],\left[\operatorname{ReH}(\mathrm{CO})_{3}\right]$ and $\left[\mathrm{RhH}(\mathrm{CO})_{2}\right]$. For $\mathrm{n}$ $=1$ and $\mathrm{V}=18$, suitable fragments could be $\mathrm{Ni}(\mathrm{CO})_{4}, \mathrm{Fe}(\mathrm{CO})_{5}, \mathrm{Cr}(\mathrm{CO})_{6}, \mathrm{HCo}(\mathrm{CO})_{4}, \mathrm{HMn}(\mathrm{CO})_{5}$, and $\mathrm{H}_{2} \mathrm{Fe}(\mathrm{CO})_{4}$. Clearly, the widely used and long-standing 18-electron rule of mono-skeletal element clusters is part and parcel of the entire cluster series universe of the transition metal carbonyl complexes. Let us take another example of $\mathrm{n}=6$ and $\mathrm{S}=$ 
86. This refers to a valence electron content of 86 for 6 skeletal elements. When we look at the table, this corresponds to series $S=14 n+2$. The cluster formula corresponding to this will be given by $F=14 n+2=\left[O s(C O)_{3}\right](6)+C O=$ $\mathrm{Os}_{6}(\mathrm{CO})_{18}+\mathrm{CO}=\mathrm{Os}_{6}(\mathrm{CO})_{19}$. However, we know that the cluster exists as $\mathrm{Os}_{6}(\mathrm{CO})_{18}{ }^{2-}$ and has an octahedral shape $\left(\mathrm{O}_{\mathrm{h}}\right)$. The special number [14] represents a vital building block for carbonyl series. Other transition metal carbonyl fragments of one skeletal element with 14 valence electron content include $\mathrm{RhH}(\mathrm{CO})_{2}$, and $\mathrm{ReH}(\mathrm{CO})_{3}$. We can construct carbonyl clusters of these fragments that correspond to $\mathrm{S}=\mathrm{V}=86$ and $\mathrm{n}=6$ where $\mathrm{S}$ means series and $\mathrm{V}$ valence electron content. Let us proceed with rhodium, $\mathrm{F}=14 \mathrm{n}+2=\left[\mathrm{Rh}(\mathrm{H})(\mathrm{CO})_{2}\right](6)+\mathrm{CO}=\mathrm{Rh}_{6}(\mathrm{H})_{6}(\mathrm{CO})_{12}+\mathrm{CO}=\mathrm{Rh}_{6}(\mathrm{CO})_{3}(\mathrm{CO})_{12}+\mathrm{CO}$ $=\mathrm{Rh}_{6}(\mathrm{CO})_{16}$. This rhodium cluster is well known and is the first one to be found to have an octahedral symmetry (Cotton and Wilkinson, 1980). In these simple operations in terms of valence electrons, [14] in the formula represents the series building block for transition metal carbonyl clusters and for the main group elements the building block is [4]. But if we use the $4 \mathrm{n}$ series for transition metal carbonyl clusters, [4] should be interpreted as [14] in order to generate cluster formulas. It can be seen that the $[2 \mathrm{H}]=[\mathrm{CO}]$ in terms of valence electron contribution to a cluster fragment or formula. Also [2] in $\mathrm{F}=14 \mathrm{n}+2$ can be replaced by [CO] or a negative charge of $(-2)$ in terms of valence electron content. That is why the osmium cluster $\mathrm{Os}_{6}(\mathrm{CO})_{19}$ may be written as $\mathrm{Os}_{6}(\mathrm{CO})_{18}{ }^{2-}$ in terms of the series. The rhenium cluster can be derived in the same manner, $\mathrm{F}=14 \mathrm{n}+2=[\operatorname{Re}(\mathrm{H})(\mathrm{CO}) 3](6)+\mathrm{CO}=\operatorname{Re}_{6}(\mathrm{H})_{6}(\mathrm{CO})_{18}+\mathrm{CO}=\operatorname{Re}_{6}(\mathrm{CO})_{3}(\mathrm{CO})_{19}=$ $\operatorname{Re}_{6}(\mathrm{CO})_{22}$. The following known octahedral rhenium carbonyls, $\operatorname{Re}_{6}(\mathrm{C})(\mathrm{CO})_{19^{2-}}{ }^{2-} \operatorname{Re}_{6}(\mathrm{C})(\mathrm{CO})_{19}(\mathrm{H})^{-}, \operatorname{Re}_{6}(\mathrm{C})(\mathrm{CO})_{18}(\mathrm{H})^{3-}$, $\operatorname{Re}_{6}(\mathrm{C})(\mathrm{CO})_{18}(\mathrm{H})_{2}{ }^{2-}$, and $\operatorname{Re}_{6}(\mathrm{H})_{7}(\mathrm{CO})_{18}{ }^{-}$, all are electronically equivalent in terms of valence electron content of 86 . Let us determine an osmium cluster of the series $S=14 n+4$ when $n=1$. For $n=1$ means we will be focusing on one skeletal atom of a fragment. Such a fragment will have $S=14(1)+4=18$ valence electrons surrounding it. Suppose we assume such fragment has an osmium atom, then the [14] building block will be [Os $\left.(\mathrm{CO})_{3}, \mathrm{~V}=8+3 \times 2=14\right]$. Therefore the formula fragment of the series $\mathrm{S}=14 \mathrm{n}+4$ when $\mathrm{n}=1$ will be given by $\mathrm{F}=14 \mathrm{n}+4=\left[\mathrm{Os}(\mathrm{CO})_{3}\right](1)+2 \mathrm{CO}=\mathrm{Os}(\mathrm{CO})_{5}$. Consider another element say, chromium. The building block of [14] will have the corresponding fragment of $\left[\mathrm{Cr}(\mathrm{CO})_{4}\right.$, $\mathrm{V}=6+4 \times 2=14]$. Hence the formula of the carbonyl complex corresponding to $14 \mathrm{n}+4$ for one skeletal atom, $\mathrm{n}=1$ will be given by $\mathrm{F}=\left[\mathrm{Cr}(\mathrm{CO})_{4}\right](1)+2 \mathrm{CO}=\mathrm{Cr}(\mathrm{CO})_{4}+2 \mathrm{CO}=\mathrm{Cr}(\mathrm{CO})_{6}$. Thus, a carbonyl cluster of a number of given fragments of a known transition metal can be derived in the same manner.

\subsection{Categorization of carbonyl Clusters Using the 14n Series Matrix Table}

The use of Table 1 to categorize a given cluster is straight forward. First of all, the valence content(S or V) of the cluster is calculated. Then the number (n) of the skeletal elements is noted. Finally you identify on the matrix where the value $\mathrm{V}$ corresponding to a given $\mathrm{n}$ is. The corresponding cluster series is read off on the top of the matrix table. A few examples will be used to illustrate this. Take $\mathrm{Os}_{3}(\mathrm{CO})_{12}$ cluster, $\mathrm{n}=3, \mathrm{~V}=48$. Moving along $\mathrm{n}=3$ axis and reaching 48, the vertical movement arrives at the series $S=14 n+6$. This means the cluster belongs to ARACHNO series. The clusters, $\mathrm{Os}_{4}(\mathrm{CO})_{14} ; \mathrm{n}=4, \mathrm{~V}=60, \mathrm{~S}=14 \mathrm{n}+4$, NIDO; $\mathrm{Os}_{5}(\mathrm{CO})_{16}, \mathrm{n}=5, \mathrm{~V}=72, \mathrm{~S}=14 \mathrm{n}+2, \mathrm{CLOSO} \mathrm{Os}_{6}(\mathrm{CO})_{18} ; \mathrm{n}=6, \mathrm{~V}$ $=84, \mathrm{~S}=14 \mathrm{n}+0$, mono-capped, $\mathrm{C}^{1} \mathrm{C}[\mathrm{M}-5]$ on trigonal bipyramid cluster; $\mathrm{Os}_{6}(\mathrm{CO})_{18}{ }^{2-}$ cluster, $\mathrm{n}=6, \mathrm{~V}=86, \mathrm{~S}=14 \mathrm{n}+2$, $\mathrm{CLOSO}^{-\mathrm{Os}_{8}}(\mathrm{CO})_{22}{ }^{2-}, \mathrm{n}=8, \mathrm{~V}=110, \mathrm{~S}=14 \mathrm{n}-2$, bi-capped cluster, $\mathrm{C}^{2} \mathrm{C}[\mathrm{M}-6]$ on an octahedral geometry; $\mathrm{Os}_{10}(\mathrm{CO})_{26}{ }^{2-}, \mathrm{n}$ $=10, V=134, S=14 n-6, C^{4} C[M-6]$ is a tetra-capped octahedral cluster; and $\mathrm{Pd}_{23}(\mathrm{CO})_{20} \mathrm{~L}_{10}, \mathrm{n}=23, \mathrm{~S}=14 \mathrm{n}-32$, $\mathrm{C}^{17} \mathrm{C}[\mathrm{M}-6]$-has 17 capped atoms and 6 nuclear cluster atoms possibly forming an octahedral shape. In the case of this palladium cluster, its valence content of 290 for $n=23$ does not appear in Table 1 . However its cluster series can be obtained by simple extrapolation. For $n=23, V=310$ when $S=14 n-12$. Now when $n=23$ and $V=290$ along the $n=$ 23 row, $\mathrm{V}$ undergoes a decrease of $310-290=20$. Therefore $\mathrm{S}$ value has to decrease by the same amount. This means the required $\mathrm{S}=14 \mathrm{n}-12-20=\mathrm{S}=14 \mathrm{n}-32$, and $\mathrm{Cp}=\mathrm{C}^{17} \mathrm{C}[\mathrm{M}-6]$. This means that the cluster has a closo octahedral complex surrounded by 17 atoms. A closo cluster refers to $S=14 n+2$ series. For [M-6] closo nuclear cluster, $n=6$ and $V=86$ as shown in Table 1. A collection of known carbonyl clusters categorized in this manner are given in Table 2. The matrix table was also utilized to categorize a number of ruthenium carbonyl clusters generated using UV Laser Desorption Mass Spectroscopy (Critchey, et al 1999). The results are shown in Tables 3 and 4.

\subsection{Vertical Movement Along the Series Matrix}

\subsubsection{The Islands of Chemical Stability}

\section{The 18-Electron Rule-14n+4}

The matrix table contains some important information. Each number in the matrix (see Table 1) represents one or more fragments some of which may be molecules or clusters. Let us consider, $(1,18)$ set. This means one transition metal skeletal element surrounded by 18 electrons. This type of notation will be used in this paper. There are many transition metal elements which satisfy this condition. Among others, these include $\mathrm{Fe}(\mathrm{CO})_{5}(1,18), \mathrm{Ni}(\mathrm{CO})_{4}(1,18)$, $\mathrm{Cr}\left(\mathrm{C}_{6} \mathrm{H}_{6}\right)_{2}(1,18), \quad \mathrm{Fe}\left(\mathrm{C}_{5} \mathrm{H}_{5}\right)_{2}(1,18), \quad \mathrm{Cr}(\mathrm{CO})_{6}(1,18), \quad \mathrm{Mo}(\mathrm{CO})_{6}(1,18), \mathrm{W}(\mathrm{CO})_{6}(1,18), \quad \mathrm{Mn}(\mathrm{CO})_{6}^{+}(1,18), \mathrm{V}(\mathrm{CO})_{6}^{-}(1,18)$, $\left(\mathrm{C}_{5} \mathrm{H}_{5}\right)_{2} \mathrm{FeH}^{-}(1,18),\left(\mathrm{C}_{4} \mathrm{H}_{4}\right) \mathrm{Fe}(\mathrm{CO})_{3}(1,18),\left(\mathrm{C}_{5} \mathrm{H}_{5}\right) \mathrm{Fe}(\mathrm{CO})_{2}(\mathrm{Cl})(1,18)$ and $\left(\mathrm{C}_{5} \mathrm{H}_{5}\right) \mathrm{Ni}(\mathrm{NO})(1,18)$. For one skeletal element surrounded by 18 electrons belongs to the first member of the $S=14 n+4$ series as shown in the matrix Table 1 . Clearly 
this is the basis of the well known 18-electron rule which has been widely used in chemistry for a long time (Langmuir, 1921; Tolman, 1972; Miessler, et al, 2014).

Adding 14 to 18 produces the second element 32 written as $(2,32)$. This means two skeletal elements surrounded by 32 valence electrons. This set also belongs to $S=14 n+4$ series. Its value is given by $S=14(2)+4=32$. Some of the fragments which fulfill this condition are $\left(\mathrm{C}_{5} \mathrm{H}_{5}\right)_{2} \mathrm{Rh}(\mathrm{CO})_{2}(2,32), \mathrm{Re}_{2}\left(\mathrm{C}_{5} \mathrm{H}_{5}\right)_{2}(\mathrm{CO})_{4}(2,32), \operatorname{Re}_{2} \mathrm{H}_{2}(\mathrm{CO})_{8}(2,32)$ and $\mathrm{Os}_{2}(\mathrm{CO})_{8}(2,32)$. The other sets of numbers are produced in the same way by adding 14 to the previous number of the valence content.

The next set of cluster set for the $\mathrm{S}=14 \mathrm{n}+4$ series is $(3,46)$. The cluster examples include $\mathrm{Os}_{3} \mathrm{H}_{2}(\mathrm{CO})_{12}, \mathrm{Re}_{3} \mathrm{H}_{3}(\mathrm{CO})_{10}{ }^{2-}$, and $\mathrm{Ru}_{3}(\mathrm{CO})_{10}{ }^{2-}$. Other sets of $\mathrm{S}=14 \mathrm{n}+2$ are $(4,60) ; \mathrm{Os}_{4}(\mathrm{CO})_{14}, \mathrm{Os}_{4} \mathrm{H}_{4}(\mathrm{CO})_{12}, \mathrm{Co}_{4}(\mathrm{CO})_{12}, \mathrm{Rh}_{4}(\mathrm{CO})_{12}, \mathrm{Ir}_{4}(\mathrm{CO})_{12}$, $\mathrm{Re}_{4} \mathrm{H}_{6}(\mathrm{CO})_{12}{ }^{2-},(5,74) ; \mathrm{Os}_{5} \mathrm{H}_{2}(\mathrm{CO})_{16}, \mathrm{Os}_{5}(\mathrm{C})(\mathrm{CO})_{14}{ }^{2-}, \mathrm{Ru}_{5}(\mathrm{C})(\mathrm{CO})_{15}$, and $\mathrm{Ru}_{5}(\mathrm{~N})(\mathrm{CO})_{14}{ }^{-}$

2.4.2 Cluster linkage of $k=2 n-1 / 2 q$ for $S=14 n+q$

The cluster number $\mathrm{k}$ can be calculated from the series formula. For $\mathrm{S}=14 \mathrm{n}+4, \mathrm{k}=2 \mathrm{n}-2$. Therefore, when $\mathrm{n}=1, \mathrm{k}=$ $2(1)-2=0 ; \mathrm{n}=2, \mathrm{k}=2(2)-2=2 ; \mathrm{n}=3, \mathrm{k}=2(3)-2=4 ; \mathrm{n}=4, \mathrm{k}=2(4)-2=6 ; \mathrm{n}=5, \mathrm{k}=2(5)-2=10-2=8$. The metal-metal skeletal linkages is related to geometrical skeletal structures for clusters of low nuclearity. For the $14 n+4$ series $\mathrm{k}=0$ for $\mathrm{n}=0$ and $\mathrm{k}=2$ for $\mathrm{n}=2$. In the case of $\mathrm{k}=2$ for $\mathrm{n}=2$ two metal atoms joined together by two linkages. Thus, there is a metal-metal bonding of bond order 2. That is, $\mathrm{M}=\mathrm{M}$, and hence the following complexes $\left(\mathrm{C}_{5} \mathrm{H}_{5}\right)_{2} \mathrm{Rh}_{2}(\mathrm{CO})_{2}, \mathrm{Re}_{2}\left(\mathrm{C}_{5} \mathrm{H}_{5}\right)_{2}(\mathrm{CO})_{4}, \mathrm{Re}_{2} \mathrm{H}_{2}(\mathrm{CO})_{8}$ and $\mathrm{Os}_{2}(\mathrm{CO})_{8}$ are expected to have metal-metal double bond. For $n=3, k=4$ implies that there 4 linkages within the 3 metal atoms. The possible linkages are of the skeletal elements M-2 to M-5 for $14 n+4$ series are shown in Figure 1.

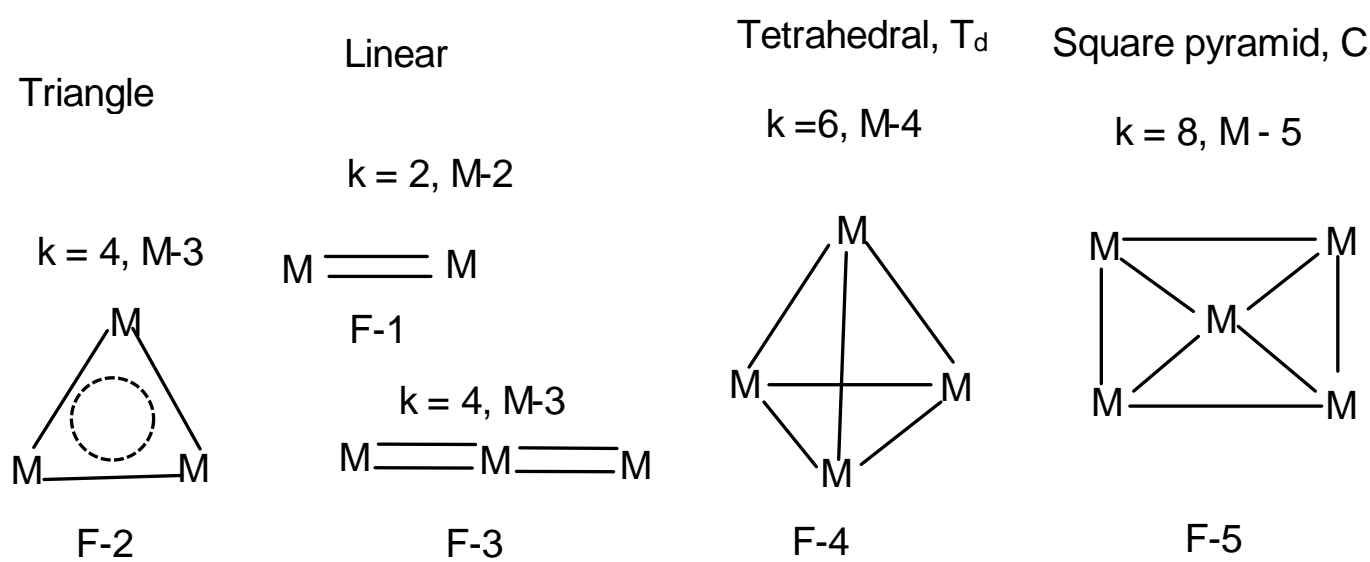

Figure 1. Sketches of Possible Linkages for $M-2$ to $M-5$ for $S=14 n+4$.

\subsubsection{The 16-Electron Rule-14n+2}

There is another interesting set of numbers, $(1,16)$. This means a single skeletal element surrounded by 16 electrons. The osmium fragment $\mathrm{Os}(\mathrm{CO})_{4}$ fulfills this condition. Some metal complexes include, $\mathrm{RhCl}\left(\mathrm{PPh}_{3}\right)_{3},\left(\mathrm{C}_{5} \mathrm{H}_{5}\right)_{2} \mathrm{TiCl}_{2}$, $\operatorname{IrCl}(\mathrm{L})_{2}(\mathrm{CO})$ where, $\mathrm{L}=2$-elctron donor, $\operatorname{Ir}(\mathrm{L})_{2}(\mathrm{CO})_{2}{ }^{-},\left(\mathrm{C}_{5} \mathrm{H}_{5}\right)_{2} \mathrm{Fe}_{2}(\mathrm{CO})_{4}$, and $\operatorname{HPtCl}(\mathrm{L})_{3}$. The $(1,16)$ set of numbers in the matrix Table 1 is the first member of $\mathrm{S}=14 n+2$ series. A number of $(1,16)$ complexes play vital roles in in catalysis(Tolman, 1972). They include, $\mathrm{Ni}(\mathrm{CO})_{3}(1,16)$ derived from $\mathrm{Ni}(\mathrm{CO})_{4}(1,18), \operatorname{RhCl}\left(\mathrm{PPh}_{3}\right)_{3}(1,16)$, and $\mathrm{HCo}(\mathrm{CO})_{3}(1,16)$ derived from $\mathrm{HCo}(\mathrm{CO}) 4(1,18)$. Could this be the basis of the 16-electron rule? Many more mono-skeletal clusters that fulfill this condition could be found. These are some of the fragments or complexes for mono-skeletal that obey the 16 electron rule. Let us consider 2 skeletal elements of $14 n+2$ series. Some examples of the complexes that are members of $14 \mathrm{n}+2$ represented by $(2,30)$ include $\mathrm{Mo}_{2}\left(\mathrm{C}_{5} \mathrm{H}_{5}\right)_{2}(\mathrm{CO})_{4}$, and $(3,44) ; \mathrm{Os}_{3}(\mathrm{CO})_{10},(4,58)$; $\mathrm{Os}_{4}(\mathrm{CO})_{13}, \mathrm{Re}_{4} \mathrm{H}_{5}(\mathrm{CO})_{12}{ }^{-} ;(5,72) ; \mathrm{Os}_{5}(\mathrm{CO})_{16}, \mathrm{Os}_{5}(\mathrm{CO})_{15}{ }^{2-}, \mathrm{PtRh}_{4}(\mathrm{CO})_{12}{ }^{2-},(6,86) ; \mathrm{Os}_{6}(\mathrm{CO})_{18}{ }^{2-}, \mathrm{Co}_{6}(\mathrm{CO})_{16}, \mathrm{Rh}_{6}(\mathrm{CO})_{16}$, $\mathrm{Ir}_{6}(\mathrm{CO})_{16}, \mathrm{Rh}_{6}(\mathrm{C})(\mathrm{CO})_{15}{ }^{2-}, \mathrm{Re}_{6}(\mathrm{C})(\mathrm{CO})_{19}{ }^{2-},(7,100) ; \mathrm{Os}_{7} \mathrm{H}_{2}(\mathrm{CO})_{21}, \mathrm{Rh}_{7}(\mathrm{~N})(\mathrm{CO})_{15}{ }^{2-}$ and $\mathrm{Co}_{7}(\mathrm{~N})(\mathrm{CO})_{15}{ }^{2-}$.

2.4.4 Cluster linkage of $k=2 n-1 / 2 q$ for $S=14 n+q$

The cluster number $\mathrm{k}$ for the series $14 \mathrm{n}+2$ are given below. For $14 \mathrm{n}+2, \mathrm{k}=2 \mathrm{n}-1$ and hence for $\mathrm{n}=1, \mathrm{k}=2(1)-1=1$; and $\mathrm{n}=2, \mathrm{k}=2(2)-1=3 ; \mathrm{n}=3, \mathrm{k}=2(3)-1=5 ; \mathrm{n}=4, \mathrm{k}=2(4)-1=7 ; \mathrm{n}=5, \mathrm{k}=2(5)-1=9, \mathrm{n}=6, \mathrm{k}=2(6)-1=11$ and $\mathrm{n}=7, \mathrm{k}$ $=2(7)-1=13$. Let us take $\mathrm{n}=2$ and $\mathrm{k}=3, \mathrm{n}=5, \mathrm{k}=9$ and $\mathrm{n}=6, \mathrm{k}=11$ and sketch possible geometries for them. These 
are shown in Figure 2.

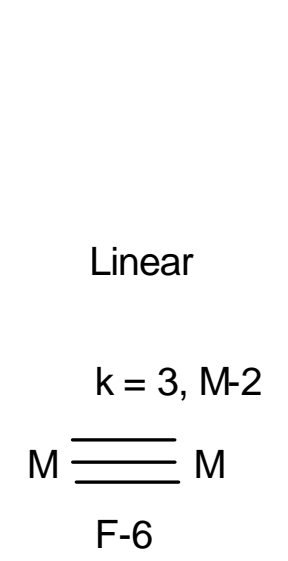

Trigonal bipyramid, $D_{3 h}$ $k=9, M-5$

Octahedral, $\mathrm{O}_{\mathrm{h}}$

$\mathrm{k}=11, \mathrm{M}-6$

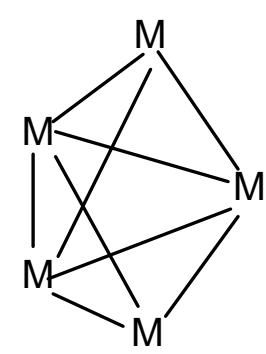

F-7

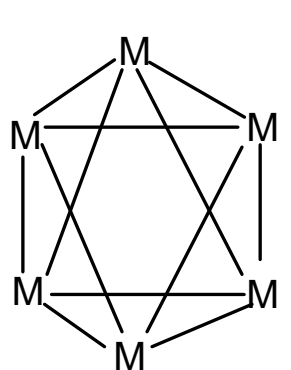

F-8

Figure 2. Sketches of Possible Linkages for M-2, M-5, M-6 for $S=14 n+2$.

Let us consider a few examples from the arachno family $S=14 n+6, k=2 n-3$. The set $(2,34)$ in which 2 skeletal atoms are surrounded by 34 valence electrons. Examples include $\mathrm{Mn}_{2}(\mathrm{CO})_{10}$, and $\mathrm{Co}_{2}(\mathrm{CO})_{8}$. For the case of the set $(3,48)$; $\mathrm{M}_{3}(\mathrm{CO})_{12}, \mathrm{M}=\mathrm{Fe}, \mathrm{Ru}$ and Os; $(6,90) ; \mathrm{Co}_{6}(\mathrm{C})(\mathrm{CO})_{15}{ }^{2-}$. For $\mathrm{n}=2, \mathrm{k}=2(2)-3=1 ; \mathrm{n}=3, \mathrm{k}=2(3)-3=3$; and $\mathrm{n}=6, \mathrm{k}$ $=2(6)-3=9$. The shapes are for $M-2$ for $k=1$, is a single metal-metal bond and for $M-3, k=3$ is a triangle and $M-6, k=$ 9, the shape normally observed is trigonal prism. The sketches of the structures are shown in Figure 3.

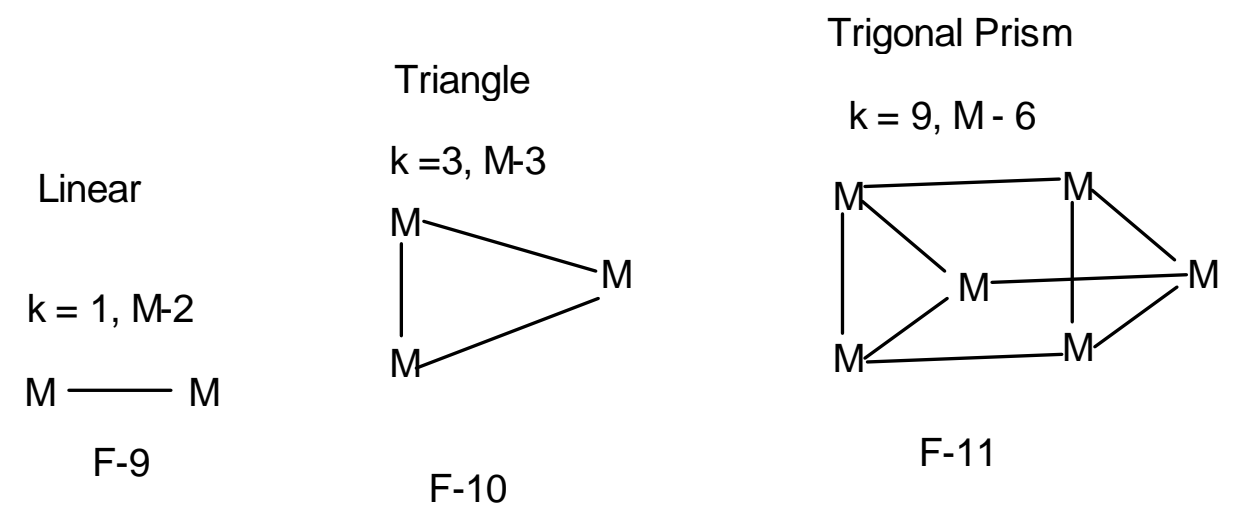

Figure 3. Sketches of Possible Linkages for M-2, M-3, M-6 for $S=14 n+6$.

\subsection{Correlation between Transition Metal Carbonyl Clusters with Main Group Clusters}

Let $u$ s consider $S=14 n+6$ for $n=2$, and $k=2 n-3=1$ The value of $S=14(2)+6=34$. This in agreement with the valence content of $\mathrm{Mn}_{2}(\mathrm{CO})_{10}$ and the presence of single metal-metal bond in the complexes. It has been shown that $14 \mathrm{n}$-based series of transition metal carbonyl clusters and fragments run parallel to the $4 \mathrm{n}$-based series of main group clusters and fragments. Hence, $14 n+6$ will correspond to $4 n+6$ of the main group elements. While the [14] electron content is utilized to form a backbone of transition metal carbonyl clusters, the [4] electron content can be used to construct the backbone of main group clusters. A natural suitable fragment is carbon [C] or boron hydrogen [BH]. In order to derive the formula main group cluster, corresponding to $\mathrm{n}=2$, we can apply $\mathrm{F}=4 \mathrm{n}+6=[\mathrm{C}](2)+6 \mathrm{H}=\mathrm{C}_{2} \mathrm{H}_{6}$. This means that $\mathrm{Mn}_{2}(\mathrm{CO})_{10}$ and $\mathrm{C}_{2} \mathrm{H}_{6}$ are isolobal or in simple terms equivalent. Furthermore, this implies that the fragment $\mathrm{CH}_{3} \leftrightarrow$ $\mathrm{Mn}(\mathrm{CO})_{5}$. Since $\mathrm{Co}_{2}(\mathrm{CO})_{8}$ is also of the set $(2,34)$, and belonging to $\mathrm{S}=14 \mathrm{n}+6$, it is also isolobal to $\mathrm{C}_{2} \mathrm{H}_{6}$ and the fragment $\mathrm{Co}(\mathrm{CO})_{4} \leftrightarrow \mathrm{CH}_{3}$. Let us consider another case of $14 n+2, k=2 n-1$ for $n=2, k=3$. The $14 n+2$ runs side by side with $4 n+2$. That is, $14 n+2 \leftrightarrow 4 n+2$. In order to find its equivalent hydrocarbon we must derive it from the series $F=$ $4 n+2$ for $n=2$, this means $F=[C](2)+2 \mathrm{H}=\mathrm{C}_{2} \mathrm{H}_{2}$. As we know well, $\mathrm{C}_{2} \mathrm{H}_{2}$ has a carbon-carbon triple bond, $\mathrm{C} \equiv \mathrm{C}$. Similarly, $\mathrm{Mo}_{2}\left(\mathrm{C}_{5} \mathrm{H}_{5}\right)_{2}(\mathrm{CO})_{4}$ is expected to have a triple bond around which the supporting ligands congregate. Its possible structure is shown in Figure 4 and that of $\mathrm{C}_{2} \mathrm{H}_{2}$ is inserted in the background for comparison. It is readily deduced that $\mathrm{CH}$ fragment is isolobal to $\left(\mathrm{C}_{5} \mathrm{H}_{5}\right) \mathrm{Mo}(\mathrm{CO})_{2}$ fragment. 
The complex $\left(\mathrm{C}_{5} \mathrm{H}_{5}\right)_{2} \mathrm{Rh}_{2}(\mathrm{CO})_{2}$ belongs to $14 \mathrm{n}+4$ series with $\mathrm{k}=2$. The series $14 \mathrm{n}+4 \leftrightarrow 4 \mathrm{n}+4$. The hydrocarbon corresponding to this for $n=2$ is given by $F=4 n+4=[C](2)+4 H=C_{2} H_{4}$. For $k=2$ for $n=2$, means that both the rhodium complex and $\mathrm{C}_{2} \mathrm{H}_{4}$ have double bonds. Their shapes are sketched in Figure 5. The structure of related diborane is added comparison.

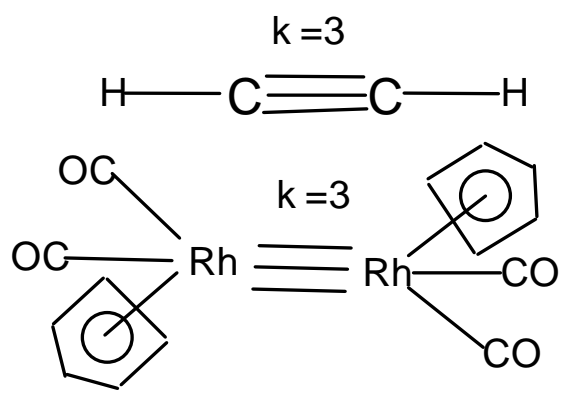

Figure 4. Possible shape of $\mathrm{Rh}_{2}\left(\mathrm{C}_{5} \mathrm{H}_{2}\right)_{2}(\mathrm{CO})_{4}$

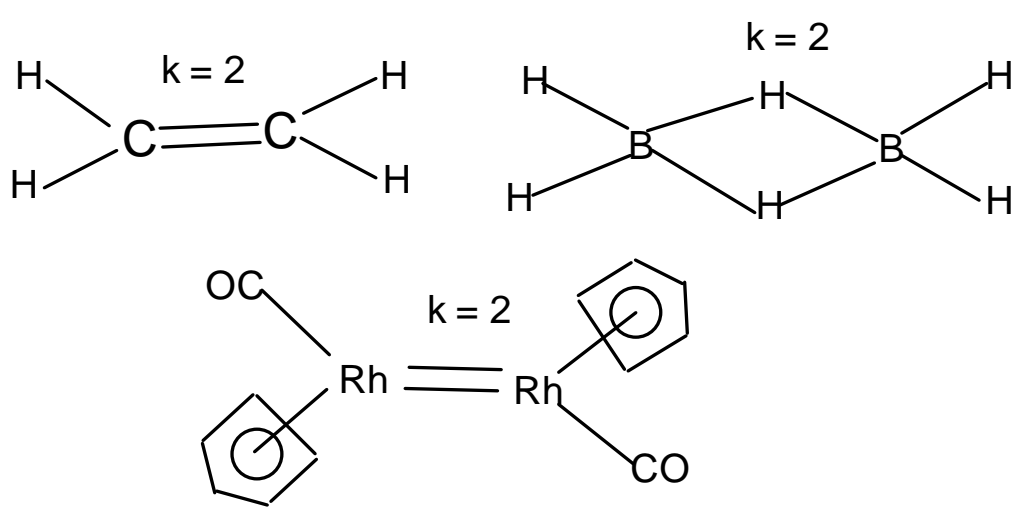

Figure 5. Possible shape of $\mathrm{Rh}_{2}\left(\mathrm{C}_{5} \mathrm{H}_{2}\right)_{2}(\mathrm{CO})_{2}$

We can also derive a borane equivalent compound in the same way we did for $\mathrm{C}_{2} \mathrm{H}_{4}$ molecule. Thus, $\mathrm{F}=4 \mathrm{n}+4$ for $\mathrm{n}=2$, $\mathrm{F}=[\mathrm{BH}](2)+4 \mathrm{H}=\mathrm{B}_{2} \mathrm{H}_{2}+4 \mathrm{H}=\mathrm{B}_{2} \mathrm{H}_{6}$.

Let us consider the complex $\mathrm{Co}_{6}(\mathrm{C})(\mathrm{CO})_{15}{ }^{2-}$. We can code the complex as $(6,90)$. This means that the 6 skeletal elements are surrounded by 90 valence electrons. It also belongs to $14 n+6$ series with $k=2 n-3=2(6)-3=9$. From the series, we can deduce that the parallel main group series is $S=4 n+6$. For $n=6$, we can also derive the corresponding hydrocarbon formula as $\mathrm{F}=4 \mathrm{n}+6=[\mathrm{C}](6)+6 \mathrm{H}=\mathrm{C}_{6} \mathrm{H}_{6}$. The carbon atom with a valence content of 4 can be used as a building block replacing [4] in the formula and replacing $\mathrm{n}$ by 6 and the last 6 in the formula substituting it with $6 \mathrm{H}$ atoms which are assumed to supply six electrons. If we were considering carbonyl clusters, 6 could be replaced by $3 \mathrm{CO}$ molecules. In summary $\mathrm{Co}_{6}(\mathrm{C})(\mathrm{CO})_{15}{ }^{2-} \leftrightarrow \mathrm{C}_{6} \mathrm{H}_{6}$. For both clusters, $\mathrm{k}=2 \mathrm{n}-3=9$. The shape of $\mathrm{Co}_{6}(\mathrm{C})(\mathrm{CO})_{15}{ }^{2-}$ is trgonal prism (see F-9 Figure 3). One of the isomers of $\mathrm{C}_{6} \mathrm{H}_{6}$ is sketched in Figure 6, F-12 for benzene and F-13 for prismane. The structure of F-13 is similar to that of F-11. However, in case of $\mathrm{C}_{6} \mathrm{H}_{6}$, many more isomers can be generated which can satisfy the requirement of $\mathrm{k}=9$. Some selected known fragments and complexes for CLOSO, NIDO and ARACHNO series respectively are indicated in trees T-1, T-2 and T-3.

\subsection{Diagonal Movement along the Cluster Matrix}

When Table 1 is examined carefully, some interesting information is discovered along the diagonal. Take the case of $(6,86)$ cluster. This set means that 6 skeletal elements are surrounded by 86 valence electrons. This electron environment usually allows the cluster to adopt an octahedral geometry $\left(\mathrm{O}_{\mathrm{h}}\right)$. Furthermore, the cluster is a member of $14 \mathrm{n}+2$ CLOSO series. A horizontal movement to the left gives $(6,84)$. This corresponds to a loss of a CO ligand or 2 electrons from $(6,86)$. The set $(6,84)$ is a beginning of capping series for CLOSO $14 n+2$ of $(5,72)$. However, a diagonal movement by one box in Table 1 gives $(7,98)$. This is the first member of the capping series of $(6,86)$-an octahedral closo cluster, which is a member $14 n+2$ series. THIS MEANS THAT THE MOVEMENT ACROSS THE DIAGONAL GIVES CLOSO CAPPING SERIES. Hence, the capping sets for octahedral $(6,86)$ are $(7,98),(8,110),(9,122),(10,134)$, $(11,146),(12,158)$ and $(13,170)$. Selected carbonyl clusters that are in agreement with these numbers are given in capping tree T-4. The set $(7,98)$ represents the first capping of the octahedral unit with a symbol, $\mathrm{C}^{1} \mathrm{C}[\mathrm{M}-6]$ of the series 
$S=14 n+0$. The next set $(8,110)$ represents the second capping with symbol $C^{2} C[M-6]$ of the series $S=14 n-2$. The other sets represent higher series. The capping series for trigonal bipyramid of closo series $14 n+2$ represented by $(5,72)$ are $(6,84),(7,76),(8,108),(9,120),((10,132), 11,144)$ and $(12,156)$. Some selected clusters that are in agreement with this are shown in the tree T-5. Sketches illustrating the capping on an octahedral closo cluster are shown in Figure 6. Let us take a last example on capping series. Starting with $(1,18)$ which represents the 18 electron rule, we move down the diagonal from right to left. The next set of numbers is $(2,30)$. This means 2 skeletal atoms surrounded by 30 valence electrons for transition metal carbonyl clusters. This set belongs to $14 n+2$ closo series. The corresponding main group series will be $4 n+2$ series. A hydrocarbon of two skeletal atoms that belongs to the series is given by $F=4 n+2=$ $[\mathrm{C}](2)+2 \mathrm{H}=\mathrm{C}_{2} \mathrm{H}_{2}$. This molecule has a triple bond $(\mathrm{C} \equiv \mathrm{C})$. Similarly any 2 skeletal atoms of transition metals of the set $(2,30)$ are expected to have a metal-metal triple bond, $M \equiv M$. Since $(2,30)$ belongs to $14 n+2$ series, the next capping set will belong to $14 n+0$. The capping involves adding [12] electrons which correspond to [12] $=[14-2]=14 n-2$ series and $\mathrm{k}=2 \mathrm{n}-(-1)=2 \mathrm{n}+1$. Since $\mathrm{n}=1$, then $\mathrm{k}=2(1)+1=3$. Thus, capping involves a step-wise increase of $\mathrm{k}$ value by 3 . The entire capping set in Table 1 is $(1,18) \rightarrow(2,30) \rightarrow(3,42) \rightarrow(4,52) \rightarrow(5,66) \rightarrow(6,78) \rightarrow(7,90) \rightarrow(8,102) \rightarrow(9,114)$. A complex that is one of the representatives of the closo series $14 \mathrm{n}+2$ is $\mathrm{Mo}_{2}(\mathrm{Cp})_{2}(\mathrm{CO})_{4}$. It has a triple bond $\mathrm{Mo} \equiv \mathrm{Mo}$. The last capping of $(2,30)$ from Table 1 is $(9,114)$. This set belongs to $S=14 n-12$ series. Its value $V=14(9)-12=126-12$ $=114$. Thus, the series formulation is correct. Let us generate a palladium carbonyl cluster that corresponds to $(9,114)$. This is readily obtained from $\mathrm{F}=14 \mathrm{n}-12=\left[\mathrm{Pd}(\mathrm{CO})_{2}\right](9)-6 \mathrm{CO}=\mathrm{Pd}_{9}(\mathrm{CO})_{18}-6 \mathrm{CO}=\mathrm{Pd}_{9}(\mathrm{CO})_{12}$. The capping symbol for this is $\mathrm{Cp}=\mathrm{C}^{1}+\mathrm{C}^{6}=\mathrm{C}^{7} \mathrm{C}[\mathrm{M}-2]$. The symbol makes sense as [M-2] represents $(2,30)$ which we have already established as being a closo system of $14 n+2$ series. Selected capping clusters based on trigonal bipyramid and octahedral closo clusters are shown in trees T-4 and T-5.

\subsection{The Movement Across the Row in the Matrix Table}

Let us consider the first row of numbers. The set $(1,18)$ means having one skeletal element surrounded by 18 valence electrons. This is the basis of the famous 18 -electron rule. There many complexes that obey this rule. These include, $\mathrm{Ni}(\mathrm{CO})_{4}, \mathrm{Fe}(\mathrm{CO})_{5}, \mathrm{Cr}(\mathrm{CO})_{6}, \mathrm{Fe}\left(\mathrm{C}_{5} \mathrm{H}_{5}\right)_{2}$, and $\left(\mathrm{C}_{4} \mathrm{H}_{4}\right) \mathrm{Fe}(\mathrm{CO})_{3}$. These complexes obey the $\mathrm{S}=14 \mathrm{n}+4$ series. These belong to the first member of the series $S=14 n+4(1,18)$. The next first set of the series $S=14 n+2$ is $(1,16)$. There are also complexes that obey the 16 electron rule. They include complexes such as $\mathrm{RhClL}_{3}, \mathrm{~L}=\mathrm{PPh}_{3},(1,16)$ Wilkinson catalyst, $\mathrm{PtCl}_{3}\left(\mathrm{C}_{2} \mathrm{H}_{4}\right)^{-}(1,16),(\mathrm{Cp})_{2} \mathrm{TiCl}_{2}(1,16), \mathrm{Cp}=\mathrm{C}_{5} \mathrm{H}_{5}, \mathrm{HRuClP}_{4}(1,16), \mathrm{P}=\mathrm{P}(\mathrm{OPh})_{3}$ and $\operatorname{IrClL}_{2}(\mathrm{CO})(1,16)$. Although such complexes were and are considered to be some of the exceptions to the 18-electron rule, it appears that are in fact the mono-skeletal complexes of the $\mathrm{S}=14 \mathrm{n}+2$ series. The complexes that satisfy $(1,16)$ condition may be considered to obey the 16-Electron rule. The complexes $(\mathrm{Cp})_{2} \mathrm{Zr}(\mathrm{R})^{+},(1,14),(\mathrm{Cp})_{2} \mathrm{Zr}(\mathrm{R})\left(\mathrm{C}_{2} \mathrm{H}_{4}\right)^{+}(1,14), \quad \mathrm{HgR}_{2}(1,14)$, and $\mathrm{MeAu}\left(\mathrm{PPh}_{3}\right)(1,14)$ could be regarded as the complexes that begin the $\mathrm{S}=14 \mathrm{n}+0$ series in the same way as the fragment $\mathrm{Os}(\mathrm{CO})_{3}$. Let us focus on the cluster members of higher nuclearity $n=6$. Consider the set $(6,90)$ of $14 n+6$ and $k=9$. This type of carbonyl cluster has 6 skeletal elements and surrounded by 90 valence electrons. The carbonyl cluster complexes that fulfill this condition take the shape of a trigonal prism (see Figure 3, F-11). When the valence electron content decreases to 86 keeping the same number of skeletal elements, the shape is transformed from trigonal prism to octahedral $(6,86)$ shape $\left(\mathrm{O}_{\mathrm{h}}\right)$, ( see Figure, F-8). The set $(6,86)$ is diagonal to the set $(5,74)$. Hence, $(6,86)$ may be considered to be a capping set of $(5,74), S=14 n+4$, NIDO and $k=8$. The set $(5,74)$ tends to adopt a square pyramid shape while the $(6,86)$ of $14 n+2$, CLOSO, $k=11$ normally takes up an octahedral shape. The set $(6,84)$ of $S=14 n+0$ lies on the diagonal of $(5,72)$ a CLOSO system of $S=14 n+2, k=9$ with a trigonal bipyramid shape( see Figure 2, F-7). The $(6,84)$ is a mono-capped cluster based on trigonal bipyramid( see Figure 7). Although it is regarded as a mono-capped trigonal bipyramid, it lies on the diagonal of very important clusters: $(3,48),(4,60),(5,72),(6,84),(7,96),(8,108)$ and so on. If the sets $(4,60),(5,72)$ and $(6,84)$ are examined closely, the set $(4,60)$ represents a tetrahedral geometry. According to the series, the capping begins with $14 n+0$ which is in line with $(6,84)$. This means that one skeletal atom is considered to be capping on 5 closo atoms [M-5] which is a trigonal bipyramid $(5,72)$. But $(5,72)$ can be regarded as mono-capped tetrahedral $(4,60)$ although $(4,60)$ is not a member of $14+0$ series. The capping atom is associated with 12 capping valence electrons. In other words, $(6,84)$ may be viewed as mono-capped trigonal bipyramid or bicapped tetrahedral or tricapped $(3,48)$-trigonal planar. The numbers after $(5,72)$ should be regarded as capping series of trigonal bipyramid. Similarly the numbers after $(6,90)$ trigonal prism diagonal such as $(7,102),(8,114),(9,126),(10,138),(11$, $150)$, and $(12,162)$ may be regarded as capping series of the trigonal prism. Let us consider the following structural changes $(6,90) \rightarrow(6,86) \rightarrow(5,74) \rightarrow(5,72)$. The set $(6,90)$ belongs to $14 \mathrm{n}+6$ arachno series and $\mathrm{k}=2 \mathrm{n}-3=2(6)-3=9$. But the set $(6,86)$ belongs to $14+2$ closo series, $\mathrm{k}=2 \mathrm{n}-1=2(6)-1=11$, and $(5,74)$ belongs to $14 \mathrm{n}+4$ with $\mathrm{k}=2 \mathrm{n}-2=2(5)-2$ $=8$. The last set $(5,72)$ belongs to $14 n+2$ closo series with $\mathrm{k}$ value of $2 \mathrm{n}-1=2(5)-1=9$. The $(6,90)$ has a trigonal prism or a raft shape. The $(6,86)$ closo cluster has an octahedral shape. Hence, the transformation $(6,90) \rightarrow(6,86)$ is structural change from trigonal prism or raft to an octahedral geometry. This involves the decrease of valence electron content by 4 while the number of skeletal atoms remains constant. The change from $(6,86) \rightarrow(5,74)$ involves the change of geometry from octahedral to square pyramid while the change from $(5,74) \rightarrow(5,72)$ involves transformation of geometry 
from square pyramid to trigonal bipyramid. These geometrical transformations are sketched in Figure 8. Correlation of valence electron content with shapes of clusters has been of intense research by chemists for some time (Hoffmann, et all, 1986; Bruce, 1986). Let us look at the simple parallel series of main group elements. We can start with (2,34) $\rightarrow(2,32) \rightarrow(2,30) \rightarrow 2,28) \rightarrow(2,26) \rightarrow(2,24)$. Since $14 \mathrm{n} \pm \mathrm{q} \leftrightarrow 4 \mathrm{n} \pm \mathrm{q}$, all we need to do is to remove $10 \mathrm{n}$, in this case $(2 \mathrm{x} 10$ $=20)$ from the valence content. If we do that the parallel 4 n series will be $(2,14) \rightarrow(2,12) \rightarrow(2,10) \rightarrow(2,8) \rightarrow(2,6)$ $\rightarrow(2,4)$. The set $(2,14)$ belongs to $4 n+6$ with $\mathrm{k}=2 \mathrm{n}-3$. A hydrocarbon the matches this is $\mathrm{F}=4 \mathrm{n}+6=[\mathrm{C}](2)+6 \mathrm{H}=\mathrm{C}_{2} \mathrm{H}_{6}$. The fluorine molecule $\mathrm{F}_{2}(\mathrm{~F}-\mathrm{F})$ also satisfies this requirement. This molecule has $\mathrm{k}$ value $=2(2)-3=1$. This means it has a single carbon- carbon bond $\mathrm{H}_{3} \mathrm{C}-\mathrm{CH}_{3}$. The set $(2,12)$ corresponds to $4 \mathrm{n}+4$ with a hydrocarbon $\mathrm{F}=[\mathrm{C}](2)+4 \mathrm{H}=$ $\mathrm{C}_{2} \mathrm{H}_{4}$. The molecule, $\mathrm{C}_{2} \mathrm{H}_{4}$ has a double bond $(\mathrm{C}=\mathrm{C})$. The oxygen molecule has a double bond $(\mathrm{O}=\mathrm{O})$ and 12 valence electrons. The set $(2,10)$ corresponds to $S=4 n+2$ with $k=2 n-1$. A suitable hydrocarbon is given by $F=4 n+2=$ $[\mathrm{C}](2)+2 \mathrm{H}=\mathrm{C}_{2} \mathrm{H}_{2}$. This has a triple bond $(\mathrm{HC} \equiv \mathrm{CH})$ with 10 valence electrons. Other diatomic species that fulfill this condition include $\mathrm{C} \equiv \mathrm{O}, \mathrm{N} \equiv \mathrm{O}^{+}$, and $\mathrm{C} \equiv \mathrm{N}^{-}$. The set $(2,8)$ belongs to $\mathrm{S}=4 \mathrm{n}+0$ series with $\mathrm{k}=2 \mathrm{n}=2(2)=4$. The chemical species that satisfy this condition are $\mathrm{C}_{2}, \mathrm{CN}^{+}, \mathrm{BN}$, and $\mathrm{CB}^{-}$. These species have recently (Shaik, et al, 2012) been shown to have a quadruple bond $\mathrm{M} \equiv \mathrm{M}$. It is quite clear that keeping the number of skeletal elements constant and decreasing the valence electron content results in the increase of the number of skeletal linkages. In the above examples we moved through the following phases, $\mathrm{M}-\mathrm{M} \rightarrow \mathrm{M}=\mathrm{M} \rightarrow \mathrm{M} \equiv \mathrm{M} \rightarrow \mathrm{M} \equiv \mathrm{M}$ by simply successively decreasing the valence electron content by 2 .
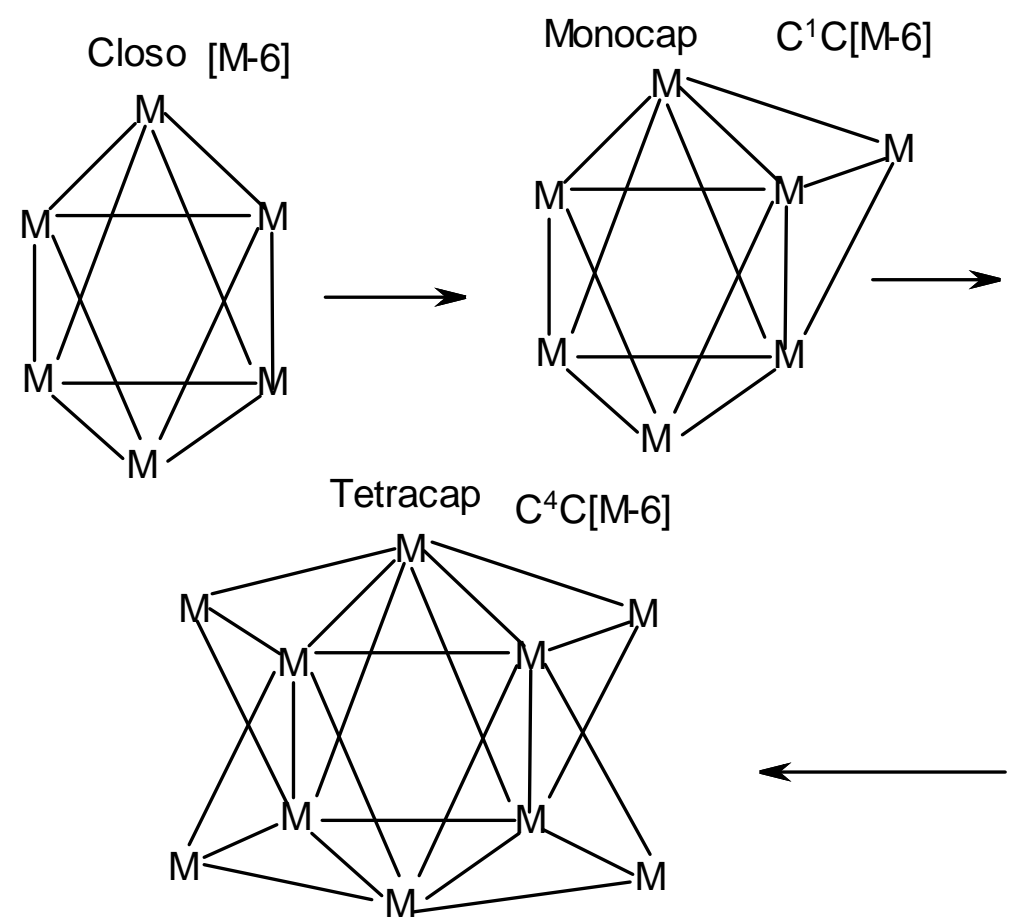

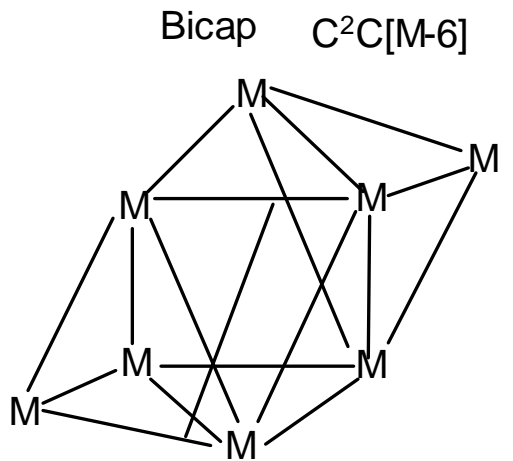

Tricap $\downarrow \mathrm{C}^{3} \mathrm{C}[\mathrm{M}-6]$

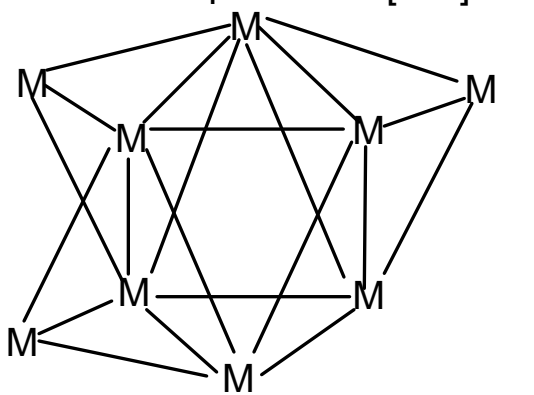

Figure 6. Sketches of some of the capping series based on Octahedral cluster

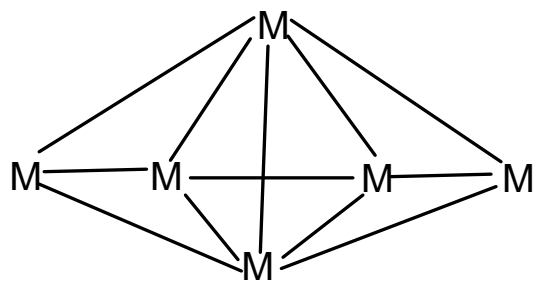

Figure 7. Sketch of skeletal elements of $(6,84)$ 
$\begin{array}{cccc}\text { Trigonal bipyramid, } \mathrm{D}_{3 \mathrm{~h}} & \text { Square pyramid } & \begin{array}{l}\text { Octahedral, } \mathrm{Oh} \\ \mathrm{k}=11, \mathrm{M}-6\end{array} & \begin{array}{l}\text { Trigonal prism } \\ \mathrm{k}=9, \mathrm{M}-6\end{array}\end{array}$

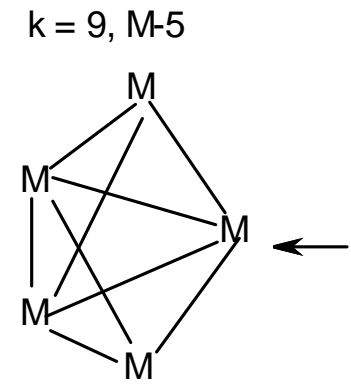

$(5,72)$

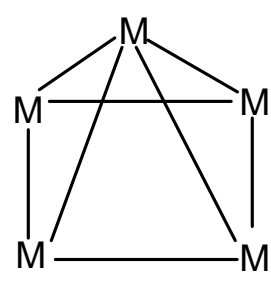

$(5,74)$

Decapping

$14 n+4$, nido

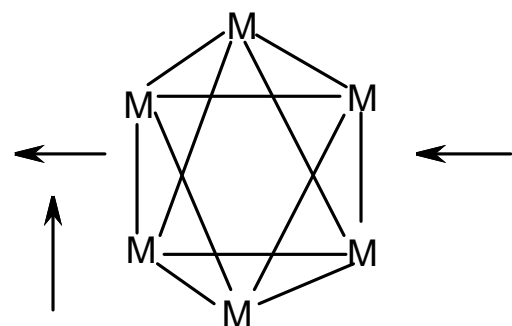

$(6,86)$

$14 n+2$, closo

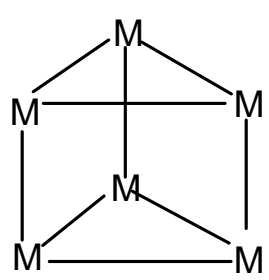

$(6,90)$

$14 n+6$, arachno

$14 n+2$, closo

Diagonal movement

Horizontal movement

Figure 8. Sketches showing an example of geometrical changes along the row (horizontal), and along the diagonal

Table 1. The Valence Content of Carbonyl Clusters in Numerical Matrix

\begin{tabular}{|c|c|c|c|c|c|c|c|c|c|c|c|c|c|}
\hline $14 n-12$ & $14 n-10$ & $14 n-8$ & $14 n-6$ & $14 n-4$ & $14 n-2$ & $14 n+0$ & $14 n+2$ & $14 n+4$ & $14 n+6$ & $14 n+8$ & $14 n+10$ & $14 n+12$ & $\mathrm{n}$ \\
\hline 2 & 4 & 6 & 8 & 10 & 12 & 14 & 16 & 18 & 20 & 22 & 24 & 26 & 1 \\
\hline 16 & 18 & 20 & 22 & 24 & 26 & 28 & 30 & 32 & 34 & 36 & 38 & 40 & 2 \\
\hline 30 & 32 & 34 & 36 & 38 & 40 & 42 & 44 & 46 & 48 & 50 & 52 & 54 & 3 \\
\hline 44 & 46 & 48 & 50 & 52 & 54 & 56 & 58 & 60 & 62 & 64 & 66 & 68 & 4 \\
\hline 58 & 60 & 62 & 64 & 66 & 68 & 70 & 72 & 74 & 76 & 78 & 80 & 82 & 5 \\
\hline 72 & 74 & 76 & 78 & 80 & 82 & 84 & 86 & 88 & 90 & 92 & 94 & 96 & 6 \\
\hline 86 & 88 & 90 & 92 & 94 & 96 & 98 & 100 & 102 & 104 & 106 & 108 & 110 & 7 \\
\hline 100 & 102 & 104 & 106 & 108 & 110 & 112 & 114 & 116 & 118 & 120 & 122 & 124 & 8 \\
\hline 114 & 116 & 118 & 120 & 122 & 124 & 126 & 128 & 130 & 132 & 134 & 136 & 138 & 9 \\
\hline 128 & 130 & 132 & 134 & 136 & 138 & 140 & 142 & 144 & 146 & 148 & 150 & 152 & 10 \\
\hline 142 & 144 & 146 & 148 & 150 & 152 & 154 & 156 & 158 & 160 & 162 & 164 & 166 & 11 \\
\hline 156 & 158 & 160 & 162 & 164 & 166 & 168 & 170 & 172 & 174 & 176 & 178 & 180 & 12 \\
\hline 170 & 172 & 174 & 176 & 178 & 180 & 182 & 184 & 186 & 188 & 190 & 192 & 194 & 13 \\
\hline 184 & 186 & 188 & 190 & 192 & 194 & 196 & 198 & 200 & 202 & 204 & 206 & 208 & 14 \\
\hline 198 & 200 & 202 & 204 & 206 & 208 & 210 & 212 & 214 & 216 & 218 & 220 & 222 & 15 \\
\hline 212 & 214 & 216 & 218 & 220 & 222 & 224 & 226 & 228 & 230 & 232 & 234 & 236 & 16 \\
\hline 226 & 228 & 230 & 232 & 234 & 236 & 238 & 240 & 242 & 244 & 246 & 248 & 250 & 17 \\
\hline 240 & 242 & 244 & 246 & 248 & 250 & 252 & 254 & 256 & 258 & 260 & 262 & 264 & 18 \\
\hline 254 & 256 & 258 & 260 & 262 & 264 & 266 & 268 & 270 & 272 & 274 & 276 & 278 & 19 \\
\hline 268 & 270 & 272 & 274 & 276 & 278 & 280 & 282 & 284 & 286 & 288 & 290 & 292 & 20 \\
\hline 282 & 284 & 286 & 288 & 290 & 292 & 294 & 296 & 298 & 300 & 302 & 304 & 306 & 21 \\
\hline 296 & 298 & 300 & 302 & 304 & 306 & 308 & 310 & 312 & 314 & 316 & 318 & 320 & 22 \\
\hline 310 & 312 & 314 & 316 & 318 & 320 & 322 & 324 & 326 & 328 & 330 & 332 & 334 & 23 \\
\hline 324 & 326 & 328 & 330 & 332 & 334 & 336 & 338 & 340 & 342 & 344 & 346 & 348 & 24 \\
\hline 338 & 340 & 342 & 344 & 346 & 348 & 350 & 352 & 354 & 356 & 358 & 360 & 362 & 25 \\
\hline 352 & 354 & 356 & 358 & 360 & 362 & 364 & 366 & 368 & 370 & 372 & 374 & 376 & 26 \\
\hline 366 & 368 & 370 & 372 & 374 & 376 & 378 & 380 & 382 & 384 & 386 & 388 & 390 & 27 \\
\hline 380 & 382 & 384 & 386 & 388 & 390 & 392 & 394 & 396 & 398 & 400 & 402 & 404 & 28 \\
\hline 394 & 396 & 398 & 400 & 402 & 404 & 406 & 408 & 410 & 412 & 414 & 416 & 418 & 29 \\
\hline 408 & 410 & 412 & 414 & 416 & 418 & 420 & 422 & 424 & 426 & 428 & 430 & 432 & 30 \\
\hline
\end{tabular}


Table 2. Known Carbonyl Clusters Categorized Using the Cluster Matrix Table

\begin{tabular}{|c|c|c|c|c|c|c|}
\hline & VALENCE & & & & & \\
\hline CLUSTER & CONTENT & $\mathrm{n}$ & CODE & SERIES & \multicolumn{2}{|c|}{ CAPPING SYMBOL } \\
\hline $\operatorname{Re}_{2}(\mathrm{CO})_{10}$ & 34 & 2 & $(2,34)$ & $4 n+6$ & \multicolumn{2}{|c|}{ ARACHNO } \\
\hline $\mathrm{Re}_{3} \mathrm{H}_{4}(\mathrm{CO})_{12}$ & 46 & 3 & $(3,46)$ & $4 n+4$ & \multicolumn{2}{|c|}{ NIDO } \\
\hline $\mathrm{Os}_{3}(\mathrm{CO})_{12}$ & 48 & 3 & $(3,48)$ & $4 n+6$ & \multicolumn{2}{|c|}{ ARACHNO } \\
\hline $\mathrm{Ir}_{4}(\mathrm{CO})_{11} \mathrm{~L}$ & 60 & 4 & $(4,60)$ & $4 n+4$ & \multicolumn{2}{|c|}{ NIDO } \\
\hline $\mathrm{Re}_{4} \mathrm{H}_{6}(\mathrm{CO})_{12}{ }^{2-}$ & 60 & 4 & $(4,60)$ & $4 n+4$ & \multicolumn{2}{|c|}{ NIDO } \\
\hline $\mathrm{Rh}_{4}(\mathrm{CO})_{12}$ & 60 & 4 & $(4,60)$ & $4 n+4$ & \multicolumn{2}{|c|}{ NIDO } \\
\hline $\operatorname{Re}_{5}(\mathrm{C})(\mathrm{H})(\mathrm{CO})_{16}{ }^{2-}$ & 74 & 5 & $(5,74)$ & $4 n+4$ & \multicolumn{2}{|c|}{ NIDO } \\
\hline $\mathrm{Rh}_{5}(\mathrm{CO})_{15}$ & 76 & 5 & $(5,76)$ & $4 n+6$ & \multicolumn{2}{|c|}{ ARACHNO } \\
\hline $\mathrm{Os}_{5}(\mathrm{CO})_{19}$ & 78 & 5 & $(5,78)$ & $4 n+8$ & \multicolumn{2}{|c|}{ HYPHO } \\
\hline $\mathrm{Rh}_{6}(\mathrm{CO})_{16}$ & 86 & 6 & $(6,86)$ & $4 n+2$ & \multicolumn{2}{|c|}{ CLOSO } \\
\hline $\mathrm{Os}_{6}(\mathrm{CO})_{18} \mathrm{H}_{2}$ & 86 & 6 & $(6,86)$ & $4 n+2$ & \multicolumn{2}{|c|}{ CLOSO } \\
\hline $\mathrm{Re}_{6} \mathrm{H}_{7}(\mathrm{CO})_{18}-$ & 86 & 6 & $(6,86)$ & $4 n+2$ & \multicolumn{2}{|c|}{ CLOSO } \\
\hline $\operatorname{Re}_{6}(\mathrm{C})(\mathrm{CO})_{19}{ }^{2-}$ & 86 & 6 & $(6,86)$ & $4 n+2$ & \multicolumn{2}{|c|}{ CLOSO } \\
\hline $\mathrm{Re}_{6} \mathrm{H}_{8}(\mathrm{CO})_{18}^{2-}$ & 88 & 6 & $(6,88)$ & $4 n+4$ & \multicolumn{2}{|c|}{ NIDO } \\
\hline $\mathrm{Os}_{6}(\mathrm{CO})_{21}$ & 90 & 6 & $(6,90)$ & $4 n+6$ & \multicolumn{2}{|c|}{ ARACHNO } \\
\hline $\mathrm{Os}_{7}(\mathrm{CO})_{21}$ & 98 & 7 & $(7,98)$ & $4 n+0$ & \multicolumn{2}{|c|}{$\mathrm{C}^{1} \mathrm{C}[\mathrm{M}-6]$} \\
\hline $\mathrm{Re}_{7} \mathrm{H}(\mathrm{C})(\mathrm{CO})_{21}^{3-}$ & 98 & 7 & $(7,, 98)$ & $4 n+0$ & \multicolumn{2}{|c|}{$\mathrm{C}^{1} \mathrm{C}[\mathrm{M}-6]$} \\
\hline $\mathrm{Rh}_{7}(\mathrm{CO})_{16}{ }^{3-}$ & 98 & 7 & $(7,98)$ & $4 n+0$ & \multicolumn{2}{|c|}{$\mathrm{C}^{1} \mathrm{C}[\mathrm{M}-6]$} \\
\hline $\mathrm{Os}_{6} \mathrm{Pt}(\mathrm{CO})_{18} \mathrm{H}_{8}$ & 106 & 8 & $(8,106)$ & $4 n-6$ & \multicolumn{2}{|c|}{$\mathrm{C}^{4} \mathrm{C}[\mathrm{M}-4]$} \\
\hline $\mathrm{Os}_{8}(\mathrm{CO})_{18}{ }^{2-}$ & 102 & 8 & $(8,102)$ & $4 n-10$ & \multicolumn{2}{|c|}{$\mathrm{C}^{6} \mathrm{C}[\mathrm{M}-2]$} \\
\hline $\mathrm{Os}_{6} \mathrm{Pt}_{2}(\mathrm{CO})_{16}(\mathrm{COD})_{2}$ & 110 & 8 & $(8,110)$ & $4 n-2$ & \multicolumn{2}{|c|}{$\mathrm{C}^{2} \mathrm{C}[\mathrm{M}-6]$} \\
\hline $\mathrm{Os}_{8}(\mathrm{CO})_{22}{ }^{2-}$ & 110 & 8 & $(8,110)$ & $4 n-2$ & \multicolumn{2}{|c|}{$\mathrm{C}^{2} \mathrm{C}[\mathrm{M}-6]$} \\
\hline $\mathrm{Re}_{8}(\mathrm{C})(\mathrm{CO})_{24}{ }^{2-}$ & 110 & 8 & $(8,110)$ & $4 n-2$ & \multicolumn{2}{|c|}{$\mathrm{C}^{2} \mathrm{C}[\mathrm{M}-6]$} \\
\hline $\mathrm{Rh}_{8}(\mathrm{C})(\mathrm{CO})_{19}$ & 114 & 8 & $(8,114)$ & $4 n+2$ & \multicolumn{2}{|c|}{ CLOSO } \\
\hline $\mathrm{Os}_{8}(\mathrm{CO})_{24}{ }^{2-}$ & 114 & 8 & $(8,114)$ & $4 n+2$ & \multicolumn{2}{|c|}{ CLOSO } \\
\hline $\mathrm{Ir}_{9}(\mathrm{CO})_{19}(\mathrm{H})^{2-}$ & 120 & 9 & & $(9,120)$ & $4 n-6$ & $\mathrm{C}^{4} \mathrm{C}[\mathrm{M}-5]$ \\
\hline $\mathrm{Rh}_{9}(\mathrm{CO})_{19}^{3-}$ & 122 & 9 & & $(9,122)$ & $4 n-4$ & $\mathrm{C}^{3} \mathrm{C}[\mathrm{M}-6]$ \\
\hline $\mathrm{Os}_{9}(\mathrm{CO})_{24}{ }^{2-}$ & 122 & 9 & & $(9,122)$ & $4 n-4$ & $\mathrm{C}^{3} \mathrm{C}[\mathrm{M}-6]$ \\
\hline $\mathrm{Os}_{6} \mathrm{Pt}_{4}(\mathrm{CO})_{22}(\mathrm{COD})$ & 124 & 10 & & $(10,124)$ & $4 n-16$ & $\mathrm{C}^{9} \mathrm{C}[\mathrm{M}-1]$ \\
\hline $\mathrm{Rh}_{10}(\mathrm{CO})_{21}$ & 134 & 10 & & $(10,134)$ & $4 n-6$ & $\mathrm{C}^{4} \mathrm{C}[\mathrm{M}-6]$ \\
\hline $\mathrm{Os}_{10}(\mathrm{CO})_{26}{ }_{2-}$ & 134 & 10 & & $(10,134)$ & $4 n-6$ & $\mathrm{C}^{4} \mathrm{C}[\mathrm{M}-6]$ \\
\hline $\mathrm{Rh}_{11}(\mathrm{CO})_{22}{ }^{3-}$ & 148 & 11 & & $(11,148)$ & $4 n-6$ & $\mathrm{C}^{4} \mathrm{C}[\mathrm{M}-7]$ \\
\hline $\mathrm{Rh}_{12}(\mathrm{C})_{2}(\mathrm{CO})_{25}$ & 166 & 12 & & $(12,166)$ & $4 n-2$ & $\mathrm{C}^{2} \mathrm{C}[\mathrm{M}-10]$ \\
\hline $\mathrm{Rh}_{13}(\mathrm{H})_{2}(\mathrm{CO})_{24}{ }^{3-}$ & 170 & 13 & & $(13,170)$ & $4 n-12$ & $\mathrm{C}^{7} \mathrm{C}[\mathrm{M}-6]$ \\
\hline $\mathrm{Rh}_{14}(\mathrm{CO})_{25}$ & 180 & 14 & & $(14,180)$ & $4 n-16$ & $\mathrm{C}^{9} \mathrm{C}[\mathrm{M}-5]$ \\
\hline $\mathrm{Rh}_{15}(\mathrm{CO})_{27}{ }^{3-}$ & 192 & 15 & & $(15,192)$ & $4 n-18$ & $\mathrm{C}^{10} \mathrm{C}[\mathrm{M}-5]$ \\
\hline $\mathrm{Rh}_{17}(\mathrm{CO})_{30}{ }^{3-}$ & 216 & 17 & & $(17,216)$ & $4 n-22$ & $\mathrm{C}^{12} \mathrm{C}[\mathrm{M}-5]$ \\
\hline $\mathrm{Rh}_{23}(\mathrm{~N})_{4}(\mathrm{CO})_{38}-$ & 304 & 22 & & $(22,304)$ & $4 n-4$ & $\mathrm{C}^{3} \mathrm{C}[\mathrm{M}-19]$ \\
\hline
\end{tabular}


Table 3. Carbonyl Clusters from Research Paper Categorized Using the Cluster Matrix Table

\begin{tabular}{|c|c|c|c|c|c|}
\hline CLUSTER & $\begin{array}{l}\text { VALENCE } \\
\text { CONTENT }\end{array}$ & $\mathrm{n}$ & CODE & SERIES & CAPPING SYMBOL \\
\hline $\mathrm{Ru}_{9}(\mathrm{CO})_{23}{ }^{2-}$ & 120 & 9 & $(9,120)$ & $4 n-6$ & $\mathrm{C}^{4} \mathrm{C}[\mathrm{M}-5]$ \\
\hline $\mathrm{Ru}_{9}(\mathrm{CO})_{22}{ }^{2-}$ & 118 & 9 & $(9,118)$ & $4 n-8$ & $\mathrm{C}^{5} \mathrm{C}[\mathrm{M}-4]$ \\
\hline $\mathrm{Ru}_{8}(\mathrm{CO})_{21}{ }^{2-}$ & 108 & 8 & $(8,108)$ & $4 n-4$ & $\mathrm{C}^{3} \mathrm{C}[\mathrm{M}-5]$ \\
\hline $\mathrm{Ru}_{8}(\mathrm{CO})_{20}{ }^{2-}$ & 106 & 8 & $(8,106)$ & $4 n-6$ & $\mathrm{C}^{4} \mathrm{C}[\mathrm{M}-4]$ \\
\hline $\mathrm{Ru}_{7}(\mathrm{CO})_{20}{ }^{2-}$ & 98 & 7 & $(7,98)$ & $4 n+0$ & $\mathrm{C}^{1} \mathrm{C}[\mathrm{M}-6]$ \\
\hline $\mathrm{Ru}_{7}(\mathrm{CO})_{19}{ }^{2-}$ & 96 & 7 & $(7,96)$ & $4 n+0$ & $\mathrm{C}^{1} \mathrm{C}[\mathrm{M}-6]$ \\
\hline $\mathrm{Ru}_{7}(\mathrm{CO})_{18}^{2-}$ & 94 & 7 & $(7,94)$ & $4 n+0$ & $\mathrm{C}^{1} \mathrm{C}[\mathrm{M}-6]$ \\
\hline $\mathrm{Ru}_{6}(\mathrm{CO})_{21}{ }^{2-}$ & 92 & 6 & $(6,92)$ & $4 n+8$ & HYPHO \\
\hline $\mathrm{Ru}_{6}(\mathrm{CO})_{20}{ }^{2-}$ & 90 & 6 & $(6,90)$ & $4 n+6$ & ARACHNO \\
\hline $\mathrm{Ru}_{6}(\mathrm{CO})_{18}{ }^{2-}$ & 86 & 6 & $(6,86)$ & $4 n+2$ & CLOSO \\
\hline $\mathrm{Ru}_{6}(\mathrm{CO})_{17}{ }^{2-}$ & 84 & 6 & $(6,84)$ & $4 n+0$ & $\mathrm{MONOCP}=\mathrm{C}^{1} \mathrm{C}[\mathrm{M}-5]$ \\
\hline $\mathrm{Ru}_{6}(\mathrm{CO})_{16}{ }^{2-}$ & 82 & 6 & $(6,82)$ & $4 n-2$ & $\mathrm{C}^{2} \mathrm{C}[\mathrm{M}-4]$ \\
\hline $\mathrm{Ru}_{6}(\mathrm{CO})_{15}{ }^{2-}$ & 80 & 6 & $(6,80)$ & $4 n-4$ & $\mathrm{C}^{3} \mathrm{C}[\mathrm{M}-3]$ \\
\hline $\mathrm{Ru}_{6}(\mathrm{CO})_{14}{ }^{2-}$ & 78 & 6 & $(6,78)$ & $4 n-6$ & $\mathrm{C}^{4} \mathrm{C}[\mathrm{M}-2]$ \\
\hline $\mathrm{Ru}_{5}(\mathrm{CO})_{15^{2-}}$ & 72 & 5 & $(5,72)$ & $4 n+2$ & CLOSO \\
\hline $\mathrm{Ru}_{5}(\mathrm{CO})_{14}{ }^{2-}$ & 70 & 5 & $(7,70)$ & $4 n+0$ & $\mathrm{MONOCP}=\mathrm{C}^{1} \mathrm{C}[\mathrm{M}-4]$ \\
\hline $\mathrm{Ru}_{5}(\mathrm{CO})_{13}{ }^{2-}$ & 68 & 5 & $(5,68)$ & $4 n-2$ & $\mathrm{C}^{2} \mathrm{C}[\mathrm{M}-3]$ \\
\hline $\mathrm{Ru}_{4}(\mathrm{CO})_{13}{ }^{2-}$ & 60 & 4 & $(4,60)$ & $4 n+4$ & NIDO \\
\hline $\mathrm{Ru}_{4}(\mathrm{CO})_{12}{ }^{2-}$ & 58 & 4 & $(4,58)$ & $4 n+2$ & CLOSO \\
\hline $\mathrm{Ru}_{3}(\mathrm{CO})_{11}{ }^{2-}$ & 48 & 3 & $(3,48)$ & $4 n+6$ & ARACHNO \\
\hline $\mathrm{Ru}_{3}(\mathrm{CO})_{10}{ }^{2-}$ & 46 & 3 & $(3,46)$ & $4 n+2$ & CLOSO \\
\hline $\mathrm{Ru}_{3}(\mathrm{CO})_{9}{ }^{2-}$ & 44 & 3 & $(3,44)$ & $4 n+2$ & CLOSO \\
\hline $\mathrm{HOs}_{5}(\mathrm{CO})_{15}-$ & 72 & 5 & $(5,72)$ & $4 n+2$ & CLOSO \\
\hline $\mathrm{PtRu}_{5}(\mathrm{C})(\mathrm{CO})_{15}{ }^{2-}$ & 86 & 6 & $(6,86)$ & $4 n+2$ & CLOSO \\
\hline $\mathrm{Os}_{10}(\mathrm{C})(\mathrm{CO})_{24}^{2-}$ & 134 & 10 & $(10,134)$ & $4 n-6$ & $\mathrm{C}^{4} \mathrm{C}[\mathrm{M}-6]$ \\
\hline $\mathrm{Os}_{17}(\mathrm{CO})_{36}{ }^{2-}$ & 210 & 17 & $(17,210)$ & $4 n-28$ & $\mathrm{C}^{15} \mathrm{C}[\mathrm{M}-2]$ \\
\hline $\mathrm{Os}_{20}(\mathrm{CO})_{40}^{2-}$ & 242 & 20 & $(20,242)$ & $4 n-38$ & $\mathrm{C}^{20} \mathrm{C}[\mathrm{M}-0]$ \\
\hline $\mathrm{Pt}_{3} \mathrm{Ru}_{10}(\mathrm{C})_{2}(\mathrm{CO})_{32}{ }^{2-}$ & 184 & 13 & $(13,184)$ & $4 n+2$ & CLOSO \\
\hline $\mathrm{Pd}_{6} \mathrm{Ru}_{6}(\mathrm{CO})_{24}$ & 158 & 12 & $(12,158)$ & $4 n-10$ & $\mathrm{C}^{6} \mathrm{C}[\mathrm{M}-6]$ \\
\hline $\mathrm{Pd}_{4}(\mathrm{CO})_{5} \mathrm{~L}_{4}$ & 58 & 4 & $(4,58)$ & $4 n+2$ & CLOSO \\
\hline $\mathrm{Pd}_{10}(\mathrm{CO})_{12} \mathrm{~L}_{6}$ & 136 & 10 & $(10,136)$ & $4 n-4$ & $\mathrm{C}^{3} \mathrm{C}[\mathrm{M}-7]$ \\
\hline $\mathrm{Pd}_{12}(\mathrm{CO})_{12} \mathrm{~L}_{6}$ & 156 & 12 & $(12,156)$ & $4 n-12$ & $\mathrm{C}^{7} \mathrm{C}[\mathrm{M}-5]$ \\
\hline $\mathrm{Pd}_{16}(\mathrm{CO})_{13} \mathrm{~L}_{9}$ & 204 & 16 & $(16,204)$ & $4 n-20$ & $\mathrm{C}^{11} \mathrm{C}[\mathrm{M}-5]$ \\
\hline $\mathrm{Pd}_{23}(\mathrm{CO})_{20} \mathrm{~L}_{10}$ & 290 & 23 & $(23,290)$ & $4 n-32$ & $\mathrm{C}^{17} \mathrm{C}[\mathrm{M}-6]$ \\
\hline
\end{tabular}

Table 4. Further Categorization of Carbonyl Clusters from Research Paper Using the Cluster Matrix Table

\begin{tabular}{llllll}
\hline CLUSTER & VALENCE & & & & \\
CONTENT & $\mathrm{n}$ & CODE & SERIES & CAPPING SYMBOL \\
\hline $\mathrm{Ru}_{3}(\mathrm{CO})_{12}$ & 48 & 3 & $(3,48)$ & $4 \mathrm{n}+6$ & ARACHNO \\
$\mathrm{Ru}_{4}(\mathrm{CO})_{14}$ & 60 & 4 & $(4,60)$ & $4 \mathrm{n}+4$ & NIDO \\
$\mathrm{Ru}_{5}(\mathrm{CO})_{16}$ & 72 & 5 & $(5,72)$ & $4 \mathrm{n}+2$ & CLOSO $=$ TBP \\
$\mathrm{Ru}_{6}(\mathrm{CO})_{18}$ & 84 & 6 & $(6,84)$ & $4 \mathrm{n}+0$ & MONOCP $=\mathrm{C}^{1} \mathrm{C}[\mathrm{M}-5]$ \\
$\mathrm{Ru}_{7}(\mathrm{CO})_{20}$ & 96 & 7 & $(7,96)$ & $4 \mathrm{n}-2$ & BICP $=\mathrm{C}^{2} \mathrm{C}[\mathrm{M}-5]$ \\
$\mathrm{Ru}_{8}(\mathrm{CO})_{22}$ & 108 & 8 & $(8,108)$ & $4 \mathrm{n}-4$ & TRICP $=\mathrm{C}^{3} \mathrm{C}[\mathrm{M}-5]$ \\
$\mathrm{Ru}_{9}(\mathrm{CO})_{24}$ & 120 & 9 & $(9,120)$ & $4 \mathrm{n}-6$ & TETRACP $=\mathrm{C}^{4} \mathrm{C}[\mathrm{M}-5]$ \\
$\mathrm{Ru}_{10}(\mathrm{CO})_{26}$ & 132 & 10 & $(10,132)$ & $4 \mathrm{n}-8$ & PENTACP $=\mathrm{C}^{5} \mathrm{C}[\mathrm{M}-5]$ \\
$\mathrm{Ru}_{11}(\mathrm{CO})_{28}$ & 144 & 11 & $(11,144)$ & $4 \mathrm{n}-10$ & HEXACP $=\mathrm{C}^{6} \mathrm{C}[\mathrm{M}-5]$ \\
$\mathrm{Ru}_{12}(\mathrm{CO})_{30}$ & 156 & 12 & $(12,156)$ & $4 \mathrm{n}-12$ & HEPTACP $=\mathrm{C}^{7} \mathrm{C}[\mathrm{M}-5]$ \\
\hline
\end{tabular}


$14 n+2$, CLOSO

$n$

$16 \rightarrow \quad \mathrm{Os}(\mathrm{CO})_{4}, \mathrm{Rh}(\mathrm{Cl})(\mathrm{L})_{3}, \mathrm{~L}=\mathrm{PPh}_{3}, \mathrm{HPt}(\mathrm{Cl})\left(\mathrm{L}_{2}\right), \mathrm{Ptgl}\left(\mathrm{C}_{2} \mathrm{H}_{4}\right)^{-}$, $\left(\mathrm{C}_{5} \mathrm{H}_{5}\right)_{2} \mathrm{TiCl}_{2}, \operatorname{Ir}(\mathrm{Cl})(\mathrm{L})_{2}(\mathrm{CO})$

(2) $30 \longrightarrow \quad \mathrm{Mo}_{2}(\mathrm{Cp})_{2}(\mathrm{CO})_{4}$

(3) $44 \longrightarrow \mathrm{Os}_{3}(\mathrm{CO})_{10}$,

(4) $58 \rightarrow \quad \mathrm{Os}_{4}(\mathrm{CO})_{13}$

(5) $72 \rightarrow \quad \mathrm{Os}_{5}(\mathrm{CO})_{16}$,

$68 \rightarrow \mathrm{Os}_{6}(\mathrm{CO})_{18^{2-}}, \mathrm{Co}_{6}(\mathrm{CO})_{16}, \mathrm{Rh}_{6}(\mathrm{CO})_{16}, \mathrm{Ir}_{6}(\mathrm{CO})_{16}$, $\mathrm{Rh}_{6}(\mathrm{C})(\mathrm{CO})_{15^{2-}}, \operatorname{Re}_{6}(\mathrm{C})(\mathrm{CO})_{19^{2-}}$

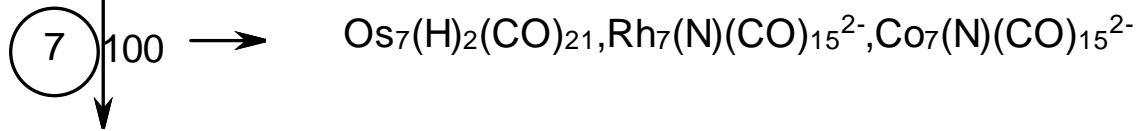

T-1 
$14 n+4$, NIDO

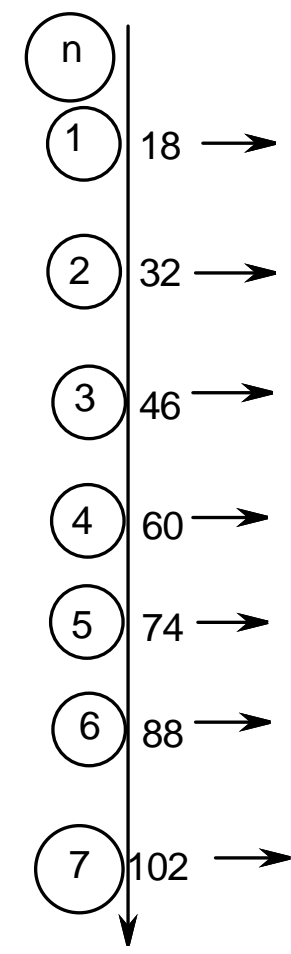

T-2 
14n+6, ARACHNO

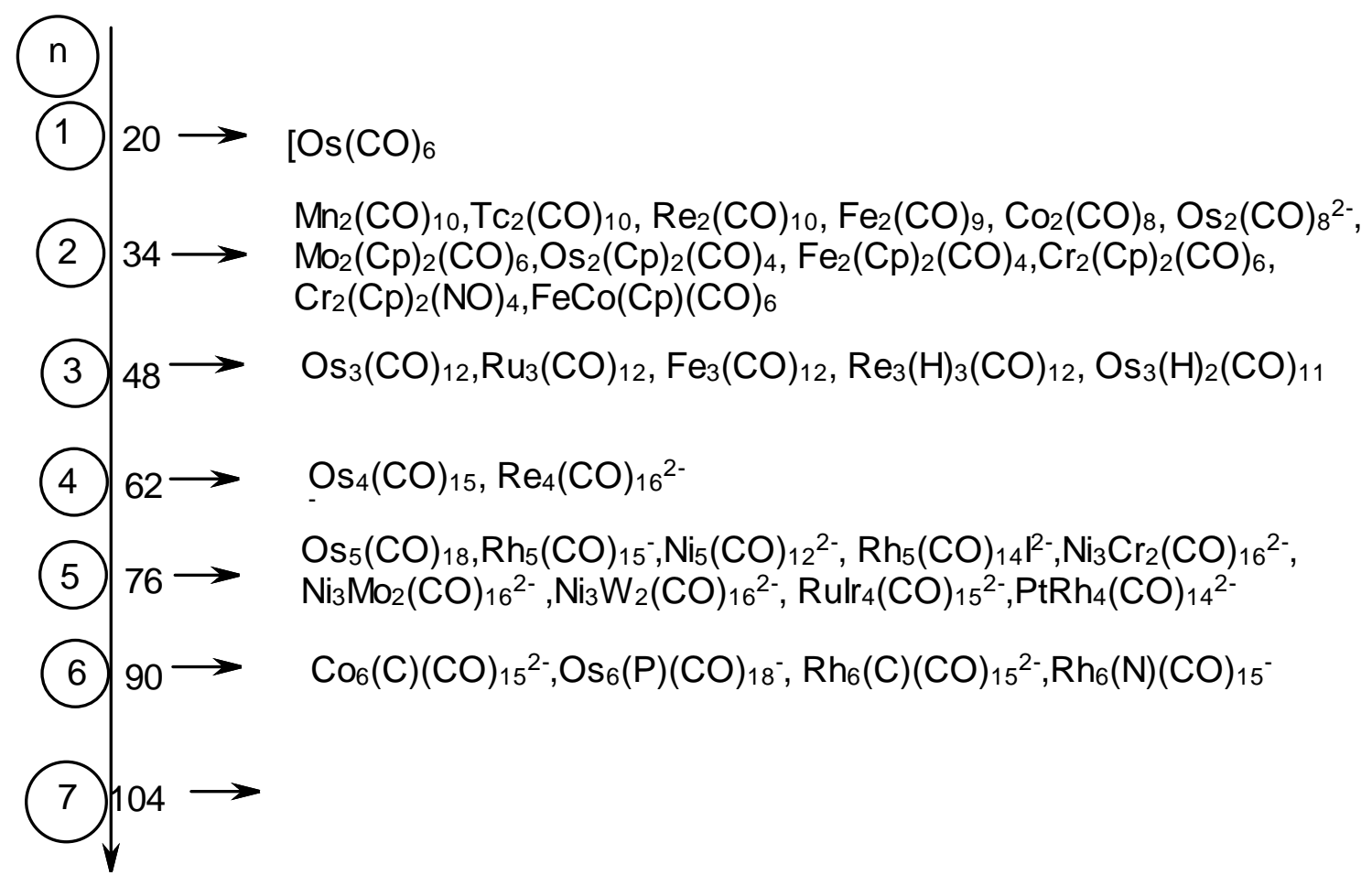

T-3 
CAPPING SERIES BASED ON TRIGONAL BIPYRAMID, [M-5]

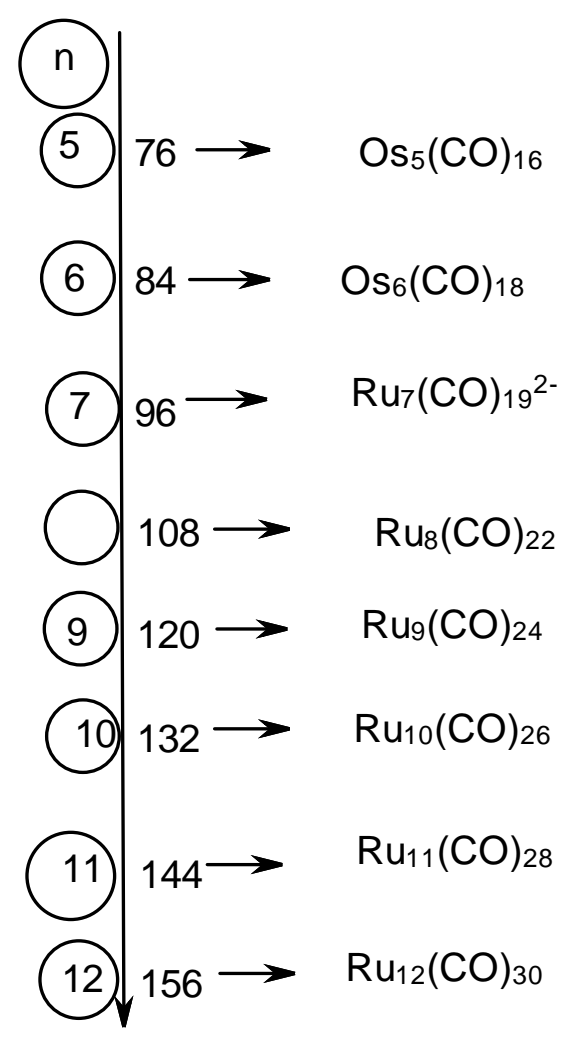

$\mathrm{T}-4$ 


\section{CAPPING SERIES BASED ON Oh, [M-6] GEOMETRY}

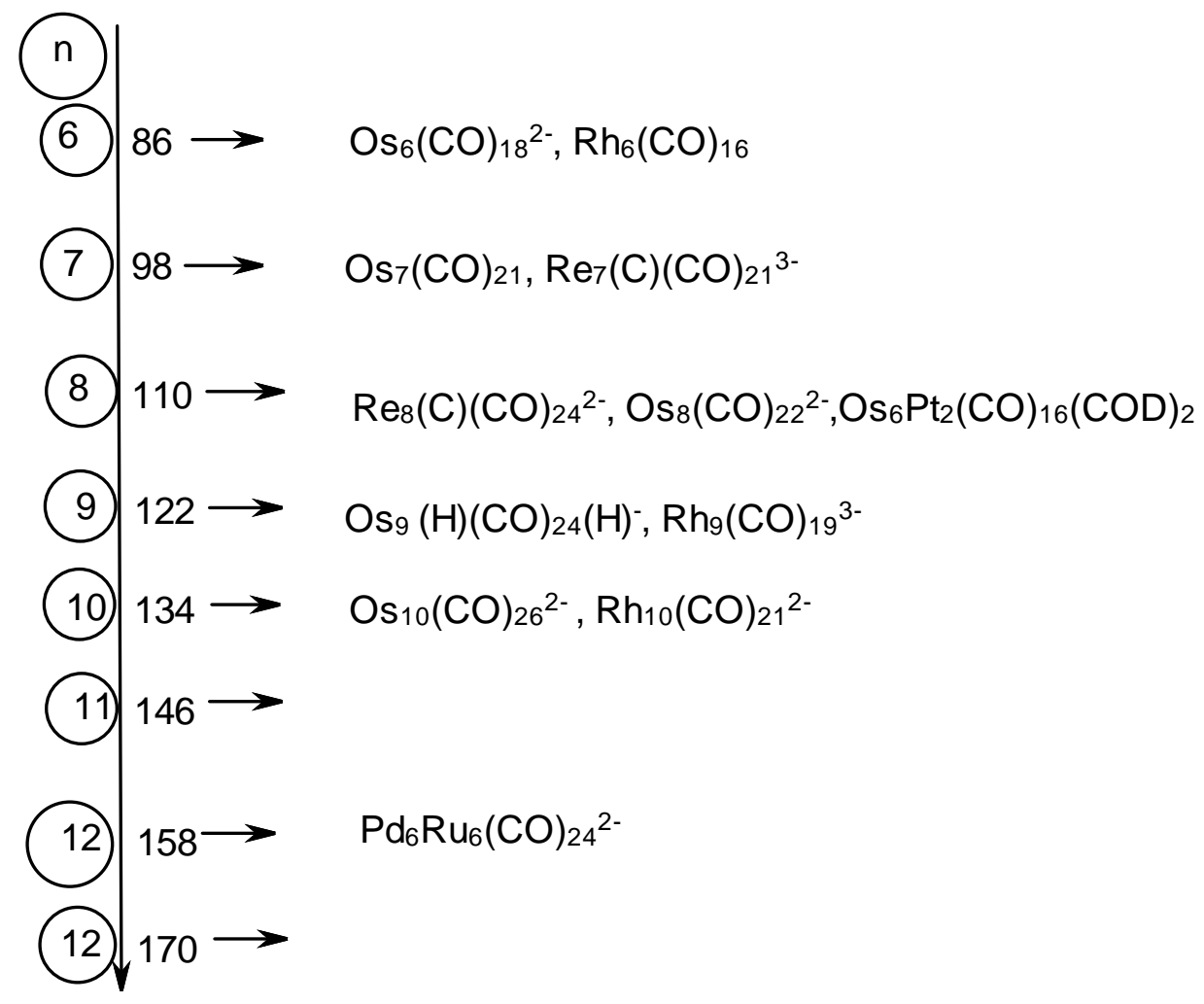

T-5

\section{Conclusion}

The array of matrix numbers in Table 1 were generated from the series $S=14 n \pm q$. It has been found that the electron valence content of carbonyl metal complexes conform to the numbers of the series matrix. The matrix clearly shows that the mono-skeletal carbonyl complexes are the first members of certain type of series which develop into multi-skeletal cluster complexes of the same series. For instance, the cluster $\mathrm{Fe}(\mathrm{CO})_{5}(1,18)$ is one of the first member of $14 n+4$ series. Other multi-nuclear complexes skeletal of the same series include $\mathrm{Rh}_{2}(\mathrm{Cp})_{2}(\mathrm{CO})_{2}(2,32), \mathrm{Os}_{4}(\mathrm{CO})_{14}(4,60)$, and $\mathrm{Os}_{5}(\mathrm{C})(\mathrm{CO})_{15}(5,74)$. The other series such as $14 \mathrm{n}+2$ beginning with $(1,16)$ $\operatorname{IrClL}_{2}(\mathrm{CO})(1,16), \mathrm{L}=$ is a phosphorous based ligand bolongs to other clan members of higher nuclearity clusters such $\mathrm{Mo}_{2}(\mathrm{Cp})_{2}(\mathrm{CO})_{4}(2,30), \mathrm{Os}_{5}(\mathrm{CO})_{16}(5,72)$ and $\mathrm{Rh}_{6}(\mathrm{CO})_{16}(6,86)$. The first members of the $14 \mathrm{n}+6,14 \mathrm{n}+4,14 \mathrm{n}+2$, $14 n+0,14 n-2,14 n-4,14 n-6$ will have the valence electron content of $20,18,16,14,12,10$ and 8 respectively. It is proposed that the sets $(1,18)$ and $(1,16)$ form the basis of the well-known 18 and 16 electron rules which are prevalent in organometallic chemistry. We may probably regard complexes such as $\mathrm{Ni}\left(\mathrm{OH}_{2}\right)_{6}{ }^{2+}(1,20), \mathrm{Ni}(\mathrm{CN})_{4}{ }^{2-}(1,20)$, $\left(\mathrm{C}_{5} \mathrm{H}_{5}\right)_{2} \mathrm{TiCl}_{2}(16), \mathrm{RhCl}\left(\mathrm{PPh}_{3}\right)_{3}(1,16), \mathrm{MR}_{2}(\mathrm{M}=\mathrm{Zn}, \mathrm{Cd}, \mathrm{Hg})(1,14), \mathrm{TiCl}_{4}(1,8)$ as first members of the respective series in Table 1. Clearly, the 18-electron rule of $14 n+4$ series that has a wide range of complexes has enjoyed the attention of science for a long time(Langmuir, 1921; Miessler,2014). The prevalence of 18-electron based complexes could imply that the 18-electron system (island of chemical stability)is more stable than 16, 14 or any other valence electron systems. The valence electron content around a cluster of skeletal elements has great influence on the shape of the skeletal elements regardless of their origin. That is, $(6,86)$ has a tendency to form an octahedral shape $\left(\mathrm{O}_{\mathrm{h}}\right)$. For example, $[\mathrm{M}-6$, $86, \mathrm{M}=\mathrm{Os}, \mathrm{Rh}, \mathrm{Re}$ ) of $\mathrm{S}=14 \mathrm{n}+2$ closo series are all expected to have an octahedral geometry. The valence electron table as written (Table 1) presents capping series along the diagonal from right to left. However, the capping series as defined by $14 n+0$ column-begins with mono-capping $\left[C^{1} C\right]$ series with the very series $14 n+0$ column. The horizontal movement from right to the left in Table 1 results in the successive increase of $\mathrm{k}$ value by 1 . On the other hand the movement along the diagonal gives a stepwise change in cluster $\mathrm{k}$ value by 3 . The movement along the column involves the successive variation of $\mathrm{k}$ value by 2 . The series matrix(Table 1) implies that the clusters especially the transition metal carbonyls are all interrelated via series. Thus, the 18 -electron rule complexes $(1,18)$ of $14 n+4$ are interrelated with those of $(2,32),(3,46),(4,60)$ and so on which belong to the $S=14 n+4$ series. There is also an interesting correlation 
between $14 \mathrm{n} \pm \mathrm{q}$ and $4 \mathrm{n} \pm \mathrm{q}$ series.

\section{Acknowledgement}

The author wishes to acknowledge the University of Namibia for providing an enabling environment and financial support, NAMSOV, Namibia for generous financial support and my wife, Merab Kambamu Kiremire for her continued encouragement to write up this paper.

\section{References}

Bruce, R. B. (1986). Metal Cluster Topology: Osmium Carbonyl Clusters. Inorg. Chim. Acta, 116, 99-107. http://dx.doi.org/10.1016/S0020-1693(00)82162-3

Cotton, F. A., \& Wilkinson, G. (1980). Advanced Inorganic Chemistry, 4th Edition, John Wiley \& Sons, New York.

Critchey, G., Dyson, P. J., Johnson, B. F. G., McIndoe, J. S., Reilly, R. K., \& Langridge-Smith, P. R. R. (1999). Reactivity and Characterization of Transition Metal Carbonyl Clusters Using UV Laser Desorption Mass Spectroscopy. Organometallics, 18, 4090-4097. http://dx.doi.org/10.1021/om990075f

Jemmis, E. D. (2005). Building relationships between polyhedral boranes and elemental boron. Inorg. Chem. 18, 620-628.

Jemmis, E. D., \& Balakrishnarajan, M. M. (2001). Polyhedral boranes and elemental boron. Direct structural relations and diverse electronic requirements. J. Am. Chem. Soc., 123, 4324-4330. http://dx.doi.org/10.1021/ja0026962

Jemmis, E. D., \& Jayasree, E. G. (2003). Analogies between boron and carbon. Acc. Chem. Res., 36, 816-824. http://dx.doi.org/10.1021/ar0300266

Jemmis, E. D., \& Pavankumar, P. N. V. (1984). Stability of Polyhedral Borane anions and Carboranes. Proc. Indian Acad. Sci., 93(3), 479-489.

Jemmis, E. D., \& Prasad, D. L. V. K. (2008). Unknowns in the chemistry of Boron. Current Science, 95(10), $1277-1283$.

Jemmis, E. D., Balakrishnarajan, M. M., \& Pancharatna, P. D. (2001). Unifying electron counting rule for Macropolyhedral Boranes, Metallaboranes, and Metallocenes. J. Am. Chem. Soc., 123(18), 4313-4323. http://dx.doi.org/10.1021/ja003233z

Jemmis, E. D., Balakrishnarajan, M. M., \& Pancharatna, P. D. (2002). Electronic Requirements for Macropolyhedral Boranes. Chem. Rev., 102(1), 93-144. http://dx.doi.org/10.1021/cr990356x

Jemmis, E. D., Jayasree, E. G., \& Parameswaran, P. (2006). Hypercarbons in polyhedral structures. Chem. Soc. Rev., 35, 157-168. http://dx.doi.org/10.1039/B310618G

King, R. B. (2002). Spherical Chemical Bonding Models for three-diamensional aromaticity in deltahedral boranes. PINSA, 68, A, 473-486.

Kiremire, E. M. (2014). Numerical Sequence of Borane Series. Orient. J. Chem., 30(3), 1055. http://dx.doi.org/10.13005/ojc/300317

Kiremire, E. M. (2015a). Categorization and Structural Determination of Simple and More Complex Carbonyl Clusters of Rhenium and Osmium Using k values and the Cluster Table. Orient. J. Chem., 31(1), $293-302$. http://dx.doi.org/10.13005/ojc/310133

Kiremire, E. M. (2015b). Classification of Transition Metal Carbonyl Clusters Using the 14n Rule Derived from Number Theory. Orient. J. Chem., 31(2), 605-618. http://dx.doi.org/10.13005/ojc/310201

Kiremire, E. M. (2015d). Isolobal Series of Chemical Fragments. Orient. J. Chem., 31(Spl. Edn), 59-70.

Kiremire, E. M. R. (2015c). Capping and Decapping Series. Int. J. Chem., 7(2), 186-197. http://dx.doi.org/10.5539/ijc.v7n2p186

Kobayashi, T., \& Xu, Q. (2007). Journal of Power Sources, 168, $167-171$. http://dx.doi.org/10.1016/j.jpowsour.2007.03.009

Langmuir, I. (1921). Types of Valence. Science, 54, 59-67. http://dx.doi.org/10.1126/science.54.1386.59

Miessler, G, Fischer, P., \& Tarr, D. (2014). Inorganic Chemistry, 5th Edition, Pearson Education, Inc., Upper Saddle River

Mingos, D. M. P. (1984). Acc. Chem. Res., 17(9), 311-319. http://dx.doi.org/10.1021/ar00105a003

Shaik, S., Danovich, D., Wu, W., Su, P., Rzepa, H. S., \& Hiberty, P. C. (2012). Quadruple bonding in C2 and analogous eight valence electron species. Nature Chemistry, 4, 195-200. http://dx.doi.org/10.1038/nchem.1263 
Stock, A. (1933). Hydrides of Boron and Silicon, Cornell University Press. Ithaca, New York.

Tolman, C, A. (1972). The 16 and 18 Electron Rule in Organometallic Chemistry and Homogeneous Catalysis. Chemical Soc. Rev., 1, 337-353. http://dx.doi.org/10.1039/cs9720100337

Wade, A. (1976). Adv. Inorg. Chem. Radiochem., 18, 1-66. http://dx.doi.org/10.1016/S0065-2792(08)60027-8

Wheeler, R. A., \& Hoffmann, R. (1986). A New Magic Cluster Electron Count and Metal-Metal Multiple Bonding. $J$. Am. Chem. Soc., 108, 6605-6610. http://dx.doi.org/10.1021/ja00281a025

\section{Copyrights}

Copyright for this article is retained by the author(s), with first publication rights granted to the journal.

This is an open-access article distributed under the terms and conditions of the Creative Commons Attribution license (http://creativecommons.org/licenses/by/3.0/). 